\title{
Predicting Efficient Antenna Ligands for Tb(III)
}

\section{Emission}

\author{
Amanda P. S. Samuel, ${ }^{\dagger *}$ Jide Xu, ${ }^{\dagger}$ Kenneth N. Raymond ${ }^{\dagger *}$
}

Contribution from the Department of Chemistry, University of California, Berkeley, CA 94720-1460

raymond@socrates.berkeley.edu

RECEIVED DATE (to be automatically inserted after your manuscript is accepted if required according to the journal that you are submitting your paper to)

TITLE RUNNING HEAD: Predicting Efficient Antenna Ligands for Tb(III) Emission

CORRESPONDING AUTHOR FOOTNOTE:

${ }^{\dagger}$ University of California, Berkeley

${ }^{+}$Lawrence Berkeley National Laboratory

ABSTRACT: A series of highly luminescent $\mathrm{Tb}(\mathrm{III})$ complexes of para-substituted 2hydroxyisophthalamide ligands (5LI-IAM-X) has been prepared $\left(\mathrm{X}=\mathrm{H}, \mathrm{CH}_{3},(\mathrm{C}=\mathrm{O}) \mathrm{NHCH}_{3}, \mathrm{SO}_{3}^{-}\right.$, $\mathrm{NO}_{2}, \mathrm{OCH}_{3}, \mathrm{~F}, \mathrm{Cl}, \mathrm{Br}$ ) to probe the effect of substituting the isophthalamide ring on ligand and $\mathrm{Tb}(\mathrm{III})$ emission in order to establish a method for predicting the effects of chromophore modification on $\mathrm{Tb}$ (III) luminescence. The energies of the ligand singlet and triplet excited states are found to increase linearly with the $\pi$-withdrawing ability of the substituent. The experimental results are supported by 
time-dependent density functional theory (TD-DFT) calculations performed on model systems, which predict ligand singlet and triplet energies within $\sim 5 \%$ of the experimental values. The quantum yield (Ф) values of the $\mathrm{Tb}(\mathrm{III})$ complex increases with the triplet energy of the ligand, which is in part due to the decreased non-radiative deactivation caused by thermal repopulation of the triplet. Together, the experimental and theoretical results serve as a predictive tool that can be used to guide the synthesis of ligands used to sensitize lanthanide luminescence.

KEYWORDS: Terbium; Luminescence; Antenna Effect; Triplet excited state energy; Coordination chemistry; Hammett parameter; TD-DFT.

\section{Introduction}

The high sensitivity and ease of detection afforded by fluorescent labels has made use of fluorescencebased bioassays very widespread. A wide variety of luminescent reporters such as organic fluorophores, ${ }^{1,2}$ fluorescent proteins, ${ }^{3,4}$ and fluorescent metal complexes ${ }^{5,6}$ and nanoparticles, ${ }^{7-9}$ have been incorporated into such systems. Among these, strategies based on lanthanide luminescence offer distinct advantages due to the unique photophysical properties (up to ms lifetimes, large Stokes shifts, narrow emission lines) of $\operatorname{Ln}(\mathrm{III})$ complexes. In particular, time-resolved luminescence-based assays utilize the long lifetimes of lanthanide complexes to increase detection sensitivity by eliminating the short-lived background fluorescence of biological samples. ${ }^{10}$

The luminescence of $\operatorname{Ln}(\mathrm{III})$ ions results from Laporte-forbidden $f-f$ transitions, which give rise to their micro- to millisecond fluorescence lifetimes. However, because they are forbidden, these transitions exhibit low extinction coefficients $\left(\varepsilon<1 \mathrm{M}^{-1} \mathrm{~cm}^{-1}\right){ }^{11}$ The weak absorbance can be overcome by coordinating chromophore-containing ligands to the metal ion, which, upon irradiation, transfer 
energy to the metal center, typically via the ligand triplet excited state, populating the Ln(III) emitting levels in a process known as the antenna effect. ${ }^{11}$ The overall quantum yield $(\Phi)$ for a sensitized Ln(III) complex is given by the equation: $\Phi=\eta_{\mathrm{ISC}} \eta_{\mathrm{ET}} \Phi^{\mathrm{Ln}}$; where $\eta_{\mathrm{ISC}}$ and $\eta_{\mathrm{ET}}$ are the respective efficiencies of intersystem crossing (ISC) and ligand-to-Ln(III) energy transfer, and $\Phi^{\mathrm{Ln}}$ is the intrinsic quantum yield of the $\operatorname{Ln}(\mathrm{III})$ ion. In terms of ligand design, this means that the antenna chromophore should: (i) be efficient at absorbing light (i.e. have large $\varepsilon$ values), (ii) have an ISC quantum yield near unity (iii) have a triplet state that is close enough in energy to the $\mathrm{Ln}(\mathrm{III})$ emitting state to allow for effective ligand-toLn(III) energy transfer (but not so close that thermal back-transfer competes effectively with $\operatorname{Ln}(\mathrm{III})$ emission) (iv) protect the $\mathrm{Ln}(\mathrm{III})$ from the quenching effects of bound water molecules. For practical use in biological applications, the ligands should also form $\mathrm{Ln}(\mathrm{III})$ complexes that are water-soluble and thermodynamically and kinetically stable.

A wide array of antenna chromophores that yield emissive $\operatorname{Ln}(\mathrm{III})$ complexes have been studied extensively, including bipyridines, ${ }^{11-14}$ calixarenes,${ }^{15-17}$ and dipicolinic acids ${ }^{18,19}$ to highlight a few. In addition, computational studies of antenna ligands and metal complexes have provided significant insight into the energy transfer process. ${ }^{20,21}$ Despite these advances, it remains difficult to easily and reliably predict the absorption and emission properties of new antenna ligands and Ln(III) complexes, without employing costly and time-consuming computational methods. The development of a simple and accurate model that can be used to screen potential antenna chromophores would represent an important advancement in the field of ligand-sensitized lanthanide luminescence.

Our previous work has shown that the 2-hydroxyisophthalamide (IAM) chromophore is an exceptionally good sensitizer of the visible Ln(III) emitters (Sm(III), Eu(III), Tb(III) and Dy(III)) while providing stable, water-soluble complexes. ${ }^{22-24}$ The IAM-based $\mathrm{Tb}(\mathrm{III})$ complexes display some of the highest quantum yield values reported in the literature of $\operatorname{Ln}(\mathrm{III})$ complexes in aqueous solution at physiological $\mathrm{pH}^{22}$ Because of their remarkable brightness, these complexes have been incorporated as 
fluorophores in commercial high-sensitivity assays. ${ }^{25}$ Using the IAM chromophore, we sought to develop a predictive tool that can be used to guide antenna ligand synthesis by studying a family of modified IAMs and their Ln(III) complexes. To this end, a series of para-substituted IAMs (5LI-IAM$\mathrm{X} ; \mathrm{X}=\mathrm{H}, \mathrm{CH}_{3},(\mathrm{C}=\mathrm{O}) \mathrm{NHCH}_{3}, \mathrm{SO}_{3}{ }^{-}, \mathrm{NO}_{2}, \mathrm{OCH}_{3}, \mathrm{~F}, \mathrm{Cl}, \mathrm{Br}$ ) (Figure 1) was synthesized. The addition of substituents to an antenna chromophore is commonly employed to alter the ligand energy levels and therefore modulate ligand-to-Ln(III) energy transfer. ${ }^{12,16,18,19,26-34}$ These tetradentate IAM ligands, which form eight-coordinate 2:1 ligand:Ln(III) complexes, serve as simplified analogs of the previously reported octa- and hexadentate ligands. The substituents cover a broad range of electron-donation and withdrawing abilities that alter singlet and triplet energies and therefore tune the ligand energy levels to optimize energy transfer to the lanthanide ion. The photophysical measurements of the 5LI-IAM-X ligands and the Tb-5LI-IAM-X complexes are reported here along with computational studies of ligand excited state energies, which together form the basis for prediction of antenna ligand and $\operatorname{Ln}(\mathrm{III})$ complex properties.

\section{Results and Discussion}

Synthesis. The nine 5LI-IAM-X ligands were synthesized according to the procedures shown in Scheme 1. To synthesize the chloro- and bromo-substituted ligands, the corresponding 2,6dimethylphenols (1a-b) were first methyl-protected using dimethyl sulfate (DMS). These dimethyl anisole derivatives (2a-b) were then oxidized with $\mathrm{KMnO}_{4}$ to give the methoxyisophthalic acids $(\mathbf{6 a - b})$. To synthesize the fluoro- and methoxy-substituted ligands, the substituted phenols (3c-d) were treated with formaldehyde in basic media to give the bis-hydroxymethylated species (4c-d). The phenolic oxygens of the bis-hydroxymethyl phenols were benzyl-protected with benzyl chloride to give 5c and 5d after which the hydroxymethyl groups were oxidized using Jones reagent ${ }^{35}$ to afford the benzyloxyisophthalic acids (6c-d). The methyl-substituted ligand was synthesized from 2,6- 
bis(hydroxymethyl)-p-cresol (4e), which was methyl-protected using DMS to give 5e. This compound was then oxidized to the acid $(\mathbf{6 e})$ with $\mathrm{KMnO}_{4}$. The nitro-substituted methoxyisophthalic acid $(\mathbf{6 g})$ was prepared by nitrating the unsubstituted $\operatorname{acid}^{36}(\mathbf{6 f})$ with a $1: 2$ mixture of $\mathrm{HNO}_{3}: \mathrm{H}_{2} \mathrm{SO}_{4}$. The parasubstituted methoxyisophthalic acids (6) were converted to the activated bis-thiazolide species (7). The bifunctionalized thiazolides were selectively coupled with methylamine under high-dilution conditions to give the mono-methylamides $(\mathbf{8})$. These methylamides were then coupled to the 1,5-diaminopentane backbone to give the protected ligands (9). The methyl protecting groups were removed using $\mathrm{BBr}_{3}$ while the benzyl protecting groups were removed by hydrogenation or under strongly acidic conditions. The sulfonated ligand (10i) was prepared by sulfonation of the unsubstituted ligand (10f) using $\mathrm{H}_{2} \mathrm{SO}_{4}$.

The Ln(III) complexes were synthesized by combining two equivalents of ligand with one equivalent of $\mathrm{LnCl}_{3} \bullet n \mathrm{H}_{2} \mathrm{O}$ in the presence of an excess of base (sym-collidine or pyridine) in methanol. After heating for several hours, the complexes were recrystallized from diethyl ether. The presence of the $\mathrm{ML}_{2}$ complex for each of the compounds was confirmed by mass spectrometry (ES-) and elemental analysis. The $\mathrm{Tb}(\mathrm{III})$ complexes, prepared in situ by combining 1 equivalent of $\mathrm{TbCl}_{3}$ (in $1 \mathrm{M} \mathrm{HCl}$ ) with 2 equivalents of ligand (in DMSO) in $0.1 \mathrm{M}$ Tris buffered $\mathrm{H}_{2} \mathrm{O}(\mathrm{pH}=7.4)$, displayed photophysical properties identical to the corresponding isolated $\mathrm{Tb}(\mathrm{III})$ complexes and therefore were used in this study to measure quantum yield and lifetime values.

Absorption and Emission. Photophysical measurements of the Ln(III) complexes of the 5LI-IAM-X series were performed to determine how the substituents affect the ligand excited states and $\operatorname{Ln}(\mathrm{III})$ emission. A summary of the results for the entire series is given in Table 1. The Tb(III) complexes (Tb$\mathbf{X})$ are very efficient absorbers, with extinction coefficients on the order of $2.3 \times 10^{4} \mathrm{M}^{-1} \mathrm{~cm}^{-1}$. Notably, this value for $\mathbf{T b}-\mathbf{N O}_{2}$ is twice as large as those of the other complexes, suggesting that this ligand experiences a larger change in dipole moment upon going from the ground to the excited state than do the other ligands. ${ }^{37}$ The $\mathrm{Tb}(\mathrm{III})$ complexes, in aqueous solution, display single ligand-centered 
absorption bands, as shown in Figure 2 in the representative absorption and emission spectra of $\mathbf{T b}-\mathbf{C l}$, with the exception of Tb-Amide, which shows one absorption band at $335 \mathrm{~nm}$ and a more intense band at $280 \mathrm{~nm}$ (Figure S2) and $\mathbf{T b}-\mathbf{N O}_{2}$, which also displays two bands, one centered at $346 \mathrm{~nm}$, and a shoulder at $\sim 380 \mathrm{~nm}$ (Figure S8). The absorption maximum of the $\mathrm{Tb}$ (III) complex of the unsubstituted ligand (Tb-H) appears at $335 \mathrm{~nm}$ (Figure S1), which is consistent with the corresponding values observed for unsubstituted octadentate IAM ligands in aqueous solution. ${ }^{22,24}$ The absorption maxima of the remaining complexes are red-shifted, ranging from $340 \mathrm{~nm}$ for $\mathbf{T b}_{-} \mathbf{S O}_{\mathbf{3}}{ }^{-}$to $359 \mathrm{~nm} \mathbf{T b}-\mathbf{O C H} \mathbf{H}_{3}$ (Figures S3-S8). Residual ligand-centered fluorescence, which can be seen in the emission spectra of the $\mathrm{Tb}$ (III) complexes, covers a similarly broad range of energies. The unsubstituted ligand (5LI-IAM-H) has a fluorescence maximum of $408 \mathrm{~nm}$, while the amide and sulfonate-substituted ligands fluoresce at slightly higher energies (405 and $404 \mathrm{~nm}$, respectively). Fluorescence maxima for the other series members are red-shifted and range from $424 \mathrm{~nm}\left(\mathbf{5 L I}-\mathbf{I A M}-\mathbf{C H}_{3}\right)$ down to $450 \mathrm{~nm}\left(\mathbf{5 L I}-\mathbf{I A M}-\mathbf{O C H}_{3}\right)$, as can be seen in Figure 2 for Tb-Cl (10a) (see also Figures S1-S8).

To determine the ligand triplet excited state energies, the emission spectra of their respective Gd(III) complexes were recorded at $77 \mathrm{~K}$ (Figures S9-S17). The lowest-energy emitting state of Gd(III), at $32,150 \mathrm{~cm}^{-1}$, is too high to be excited by the antenna ligands used in this study. Consequently, emission spectra of the Gd(III) complexes show exclusively ligand-centered emission. ${ }^{38}$ The emission spectra were de-convoluted to determine the $0-0$ vibrational transition energy $\left(T_{0-0}\right)$. The $T_{0-0}$ state of the unsubstituted ligand (5LI-IAM-H), at $23,330 \mathrm{~cm}^{-1}(429 \mathrm{~nm})$, is $\sim 3,000 \mathrm{~cm}^{-1}$ higher in energy than the emitting ${ }^{5} \mathrm{D}_{4}$ transition of $\mathrm{Tb}(\mathrm{III})\left(20,400 \mathrm{~cm}^{-1}\right)$, and is therefore in the range proposed for optimal ligand-to- $\mathrm{Tb}(\mathrm{III})$ energy transfer. ${ }^{24}$ The amide and $-\mathrm{SO}_{3}{ }^{-}$substituents result in higher energy $\mathrm{T}_{0-0}$ states: $23,970 \mathrm{~cm}^{-1}(417 \mathrm{~nm})$ and $23,870 \mathrm{~cm}^{-1}(419 \mathrm{~nm})$, respectively. The $\mathrm{T}_{0-0}$ states of the remaining ligands are red-shifted relative to 5LI-IAM-H with 5LI-IAM-NO $\mathbf{2}_{2}$ and 5LI-IAM-OCH $\mathbf{H}_{3}$ having the lowest energy $\mathrm{T}_{0-0}$ states, at $21,410 \mathrm{~cm}^{-1}(467 \mathrm{~nm})$ and $19,860 \mathrm{~cm}^{-1}(504 \mathrm{~nm})$, respectively. The 5LI-IAM- 
$\mathbf{O C H}_{3}$ triplet state is more than $500 \mathrm{~cm}^{-1}$ below the ${ }^{5} \mathrm{D}_{4}$ emitting state and is therefore not expected to sensitize $\mathrm{Tb}(\mathrm{III})$ emission at room temperature. ${ }^{31}$

The Hammett substitutent parameters ${ }^{39} \sigma_{\mathrm{p}}$, and the inductive/field $(\boldsymbol{F})$ and resonance $(\boldsymbol{R})$ component parameters were examined to see if they correlated with the absorption and emission energies of the IAM chromophores. Such a correlation would provide a preliminary strategy for IAM-ligand design. No correlation was observed between the $\sigma_{\mathrm{p}}$ parameters and the absorption and emission energies; however linear relationships were seen between the resonance component of the Hammett parameters, $\boldsymbol{R}$, and the ligand absorption and emission data. This indicates that the substituent's main influence is via interaction with $\pi$-system of the chromophore. Similar correlations have been observed for other comparable para-substitued chromophores, such as diphenylboron-2(pyrazolyl)aniline chelates. ${ }^{40}$ The absorption, fluorescence, and phosphorescence energies of the 5LI-IAM-X ligands all increase linearly with the $\pi$-withdrawing ability of the substituents (i.e., with increasing $\boldsymbol{R}$ values) (Figure 3 ), with the exception of 5LI-IAM-NO2, which has relatively low singlet and triplet energies despite the fact that the $-\mathrm{NO}_{2}$ group is strongly $\pi$-withdrawing $(\boldsymbol{R}=0.13)$. This deviation is explained by the TD-DFT results (vide infra). Significantly, the slopes of the correlation lines differ, indicating that the response of the absorption, fluorescence and phosphorescence energies to the effect on the ligand electronic structure caused by the substituents also differs. The substituent influence is greater for the fluorescence energies than for the absorption energies and greater still for the $\mathrm{T}_{0-0}$ energies. Consequently, as the $\pi$ withdrawing ability of the substituent increases, the singlet and triplet state energies also increase, while the singlet-triplet energy gaps decrease (Figure S18)

To determine how altering the ligand energy levels of the IAM-X chromophores through substitution affects $\mathrm{Tb}(\mathrm{III})$ sensitization, the emission spectra of the $\mathrm{Tb}(\mathrm{III})$ complexes and the luminescence quantum yields $(\Phi)$ were measured. The spectra show the characteristic bands corresponding to transitions from the ${ }^{5} \mathrm{D}_{4}$ emitting state to the ${ }^{7} \mathrm{~F}_{\mathrm{J}}$ ground state manifold (Figure 2). The luminescence 
quantum yield values for overall energy transfer for the $\mathrm{Tb}(\mathrm{III})$ complexes were measured relative to quinine sulfate $(\Phi=0.546){ }^{41}$ The $\Phi$ values range from 0.40 for $\mathbf{T b}$-Amide to 0 for $\mathbf{T b}-\mathbf{O C H} \mathbf{3}$ and $\mathbf{T b}$ $\mathbf{N O}_{2}$. From these data it can be seen that generally, the $\Phi$ values increase with $\mathrm{T}_{0-0}$ (Figure 4 ), which can be attributed in part to the increase in the $\mathrm{T}_{0-0}-{ }^{5} \mathrm{D}_{4}$ energy gap, which decreases non-radiative deactivation caused by repopulation of the triplet via back-transfer from the ${ }^{5} \mathrm{D}_{4}$ state (i.e. increased $\left.\Phi_{\mathrm{ET}}\right)^{42}$ Additionally, for this ligand system, increased $\mathrm{T}_{0-0}$ energies are associated with decreased singlet-triplet energy gaps. Moving to more $\pi$-withdrawing substituents therefore also influences $\eta_{\text {ISC. }}$ The observed $\mathrm{T}_{0-0}-\Phi$ relationship for the 5LI-IAM-X series is consistent with previous reports relating antenna ligand triplet energies and the quantum yield values of the resulting $\mathrm{Tb}(\mathrm{III})$ complexes, which suggest that the antenna triplet levels should be $\sim 1,500-1,700 \mathrm{~cm}^{-1}$ higher in energy than the $\operatorname{Ln}(\mathrm{III})$ emitting state to achieve efficient sensitization. ${ }^{31,43}$ For the Tb-5LI-IAM-X complexes, $\Phi$ values decrease gradually as the $\mathrm{T}_{0-0}-{ }^{5} \mathrm{D}_{4}$ energy gap is lowered from $\sim 3,500 \mathrm{~cm}^{-1}$ (Tb-Amide) to $\sim 1,600$ $\mathrm{cm}^{-1}\left(\mathbf{T b}-\mathbf{C H}_{3}\right)$, and then plummet when the energy gap shrinks to $\sim 600 \mathrm{~cm}^{-1}(\mathbf{T b}-\mathbf{F})$. Latva and coworkers observed a similarly sharp drop-off in quantum yield values as the antenna triplet energies went below $\sim 22000 \mathrm{~cm}^{-1}$. $^{31}$ Although looking at energy transfer efficiency only in terms of the antenna triplet levels is an oversimplification of the energy transfer process, the $T_{0-0}-{ }^{5} \mathrm{D}_{4}$ relationship is nonetheless a useful trend to guide ligand design, especially when looking at a single class of antenna ligands.

As previously mentioned, both $\mathbf{T b}-\mathbf{N O}_{2}$ and $\mathbf{T b}-\mathbf{O C H} \mathbf{C H}_{3}$ show no metal-based emission. The triplet energy of 5LI-IAM-OCH $\mathbf{C H}_{3}$ is below the ${ }^{5} \mathrm{D}_{4}$ emitting state and so this ligand is not expected to sensitize $\mathrm{Tb}(\mathrm{III})$ emission at room temperature due to competing thermal repopulation of the ligand triplet. ${ }^{11}$ As this quenching effect is significantly diminished upon cooling, at $77 \mathrm{~K} \mathrm{~Tb}(\mathrm{III})$-based emission is seen for this complex (Figure S19). The triplet energy of 5LI-IAM-NO $\mathbf{O}_{2}$, however is $\sim 1,000 \mathrm{~cm}^{-1}$ above the ${ }^{5} \mathrm{D}_{4}$ emitting state and only $\sim 200 \mathrm{~cm}^{-1}$ below the 5LI-IAM-F triplet state, so it is, at first glance, surprising 
that not even weak $\mathrm{Tb}(\mathrm{III})$ emission for $\mathbf{T b}-\mathbf{N O}_{2}$ is seen at room temperature. This observation, however, can be rationalized based on TD-DFT results (vide infra). The photophysical properties of $\mathbf{T b}-\mathbf{B r}$ are also unexpected, given that the triplet energies of 5LI-IAM-Br and 5LI-IAM-Cl are nearly equivalent. We are currently investigating the source of this behavior, which we believe to be a heavyatom effect of the $\mathrm{Br}$.

Lifetime Measurements. To determine if bound water molecules were contributing the observed variation in quantum yield values, and to better characterize the sensitization process, the lifetimes of the $\mathrm{Tb}(\mathrm{III})$ complexes were measured in both $\mathrm{H}_{2} \mathrm{O}$ and $\mathrm{D}_{2} \mathrm{O}$ at room temperature and at $77 \mathrm{~K}$ (Table 1 ). The lifetime data for all of the complexes were fit to mono-exponential decays, which confirm the presence of single $\mathrm{Tb}(\mathrm{III})$ emitting species in solution. In $\mathrm{H}_{2} \mathrm{O}$, at room temperature, the $\mathbf{T b}-\mathbf{H}, \mathbf{T b}$ Amide, $\mathbf{T b}-\mathbf{C l}$, and $\mathbf{T b}-\mathbf{C H}_{3}$ complexes display luminescence lifetimes on the order of $2 \mathrm{~ms}$, which are consistent with lifetimes observed for known Tb-IAM complexes. ${ }^{24}$ The lifetime of $\mathbf{T b}^{2} \mathbf{S O}_{\mathbf{3}}{ }^{-}$is significantly shorter, at $1.23 \mathrm{~ms}$. This shortened lifetime is not due to solvent quenching, since the number of bound water molecules $(q)$ estimated from the lifetime data in $\mathrm{H}_{2} \mathrm{O}$ and $\mathrm{D}_{2} \mathrm{O}$ for this complex is $0.2 .^{44}$ Indeed, for these five complexes, the near-zero $q$ values indicate that the 5LI-IAM scaffold effectively protects the $\mathrm{Tb}(\mathrm{III})$ ion from direct coordination of solvent. For $\mathbf{T b}-\mathbf{S O}_{\mathbf{3}}{ }^{-}$, the relatively short lifetime is likely due to a difference in the $\mathrm{Tb}(\mathrm{III})$ coordination environment for this complex, in comparison to the others, as indicated by the change in the relative intensities of the ${ }^{5} \mathrm{D}_{4} \rightarrow{ }^{7} \mathrm{~F}_{\mathrm{J}}$ peaks. For $\mathbf{T b}-\mathbf{S O}_{\mathbf{3}}{ }^{-}$, in contrast to $\mathbf{T b}-\mathbf{H}$ for example, the intensities of the ${ }^{5} \mathrm{D}_{4} \rightarrow{ }^{7} \mathrm{~F}_{6,4,3,2,1,0}$ transitions relative to the ${ }^{5} \mathrm{D}_{4} \rightarrow{ }^{7} \mathrm{~F}_{5}$ transition are markedly decreased (Figure 5). For $\mathrm{Tb}\left(\mathrm{III}\right.$ ), the ${ }^{5} \mathrm{D}_{4} \rightarrow{ }^{7} \mathrm{~F}_{6,4,2}$ transitions in particular show some sensitivity to the $\mathrm{Tb}(\mathrm{III})$ coordination environment. ${ }^{45}$

The lifetimes of $\mathbf{T b}-\mathbf{C l}$ and $\mathbf{T b}-\mathbf{M e}$, at 1.98 and $2.04 \mathrm{~ms}$, respectively, are slightly shortened compared to that of $\mathbf{T b}-\mathbf{H}$ (2.52 ms), which is consistent with increased back-transfer occurring in these two complexes. That effect is most pronounced for $\mathbf{T b}-\mathbf{F}$, whose ligand triplet energy is only $\sim 1,100 \mathrm{~cm}^{-1}$ 
higher in energy than the ${ }^{5} \mathrm{D}_{4}$ emitting state, and which displays a significantly shortened lifetime of $0.650 \mathrm{~ms}$ in $\mathrm{H}_{2} \mathrm{O}$ at room temperature. Interestingly, $\mathbf{T b}-\mathbf{B r}$ also has a relatively short lifetime $(0.943$ ms) in $\mathrm{H}_{2} \mathrm{O}$ at room temperature, although, as mentioned earlier, the 5LI-IAM-Br triplet state is nearly equivalent in energy to that of 5LI-IAM-Cl and Tb-Cl shows only minor decreases in quantum yield and lifetime compared to $\mathbf{T b}-\mathbf{H}$. While the source of $\mathbf{T b}-\mathbf{B r}$ 's short lifetimes and low quantum yield at room temperature are not completely understood, they do not appear to be due to the presence bound water, but rather to a thermal deactivation pathway. The effect of thermal back-transfer is reflected in the differences in lifetimes observed for the complexes at room temperature and at $77 \mathrm{~K} .^{11}$ For $\mathbf{T b}$ Amide, $\mathbf{T b}_{\mathbf{S}} \mathrm{SO}_{\mathbf{3}}{ }^{-}$, and $\mathbf{T b}-\mathbf{H}$, which have the highest quantum yield values and whose ligands have the highest triplet energies, the lifetimes are invariant, within experimental error, upon cooling the sample from room temperature to $77 \mathrm{~K}$. Tb-Me, $\mathbf{T b}-\mathbf{C l}, \mathbf{T b}-\mathbf{F}$, and $\mathbf{T b}-\mathbf{B r}$ in comparison show significant changes in lifetime upon cooling to $77 \mathrm{~K}$, which indicates that thermally-induced quenching is occurring with these complexes.

Theoretical Investigation of Ligand Excited States. With the experimental results in hand, timedependent density functional theory (TD-DFT) calculations were performed using Gaussian $03^{46}$ to gain further insight into the how the substituents affect ligand excited states. More importantly, these calculations can serve as a quick screening method to aid in the design of antenna chromophores. In order to simplify the calculations, only one bidentate IAM unit was used in the input structure and the Ln(III) was replaced with $\mathrm{Na}^{+}$(Figure 6). Gutierrez et al. have previously shown that such structures are reasonable analogs of multidentate $\mathrm{Tb}(\mathrm{III})$ complexes in calculations of this nature. ${ }^{47}$ They were, however, only able to reproduce relative positions of ligand triplet states as their calculated values were $\sim 2,500 \mathrm{~cm}^{-1}$ lower in energy than experimental values. ${ }^{47}$ To evaluate the accuracy of the calculations, the lowest-energy calculated triplet states were compared to the measured $\mathrm{T}_{1}$ values for each complex and the calculated singlet states with the largest oscillator strengths were compared to the absorption maxima $\left(\lambda_{\max }^{\mathrm{ab}}\right)$ of the complexes. The calculated wavelengths are within a few $\mathrm{nm}$ of the experimental 
values (Table 2), with the exception of the nitro-substituted species, for which the calculated lowestenergy triplet is $31 \mathrm{~nm}\left(1,330 \mathrm{~cm}^{-1}\right)$ lower than the measured triplet. Examining the molecular orbitals for the transitions shows that the singlet-singlet and singlet-triplet transitions of the ligands are $\pi$ - $\pi^{*}$ in nature, except for the nitro-substituted ligand (5LI-IAM-NO $\mathbf{O}_{2}$, which has intra-ligand charge transfer (ILCT) contributions (Figure 7). This supports the finding that the ligand $\mathrm{T}_{0-0}$ energies correlate to the $\pi$-withdrawing/donating ability of the substituent and also provides an explanation for the aberrant behavior of 5LI-IAM-NO $\mathbf{N O}_{2}$ and its $\mathrm{Tb}(\mathrm{III})$ complex; this ligand deviates from the Hammett correlations seen for the other ligands because the electronic transition is different. The presence of an ILCT state for 5LI-IAM-NO $\mathbf{N O}_{2}$ implies that such states may lie lower in energy than the ligand triplet, or that the emission lifetime is too short to allow for energy transfer to the ${ }^{5} \mathrm{D}_{4}$ state. At $77 \mathrm{~K}$, the ILCT would be higher in energy and longer-lived than at room temperature, as stabilization due to solvent reorganization is slowed, and $\mathrm{Tb}(\mathrm{III})$ emission should be observed. ${ }^{48}$ Indeed, at $77 \mathrm{~K}$, the emission spectrum of $\mathbf{T b}-\mathbf{N O}_{2}$ (Figure S20) shows metal-based emission. It should be noted that emission of $\mathbf{T b}-$ $\mathbf{N O}_{2}$ at $77 \mathrm{~K}$ can, in part, also possibly be attributed to eliminating thermal back transfer, which likely contributes to quenching at room temperature.

\section{Conclusions}

Para-substitution of the IAM ligand produces significant changes in the ligand excited state energies and consequent $\mathrm{Tb}(\mathrm{III})$ emission. Quantum yield and lifetime measurements of the $\mathrm{Tb}(\mathrm{III})$ complexes and low temperature emission studies of the $\mathrm{Gd}(\mathrm{III})$ complexes, together with a theoretical study of the ligand series, have provided a clear view of how the substituents ultimately impact $\operatorname{Ln}(\mathrm{III})$ emission and help explain the remarkable brightness of Tb-IAM complexes. Overall, the 5LI-IAM-X series provides a quantitative measure of substituent effects on ligand energy levels and on the emission intensity of the corresponding $\mathrm{Tb}(\mathrm{III})$ complexes. Time-dependent density functional theory calculations of the $\mathrm{Na}^{+}$ 
analogs of simplified, bidentate ligands reproduce the experimental values with remarkable accuracy. Ultimately, these complementary tools serve as a guide to inform the design of new ligands to produce more highly luminescent lanthanide complexes.

\section{Experimental Section}

\section{General}

All chemicals were obtained from commercial suppliers and used without further purification unless otherwise noted. Flash silica gel chromatography was performed using Merck 40-70 mesh silica gel. ${ }^{1} \mathrm{H}$ and ${ }^{13} \mathrm{C}$ NMR spectra (recorded at ambient temperature on Bruker FT-NMR spectrometers), elemental analyses, and mass spectra were obtained at the corresponding analytical facility in the College of Chemistry, University of California, Berkeley.

\section{i. 5-Chloro-2-methoxy-1,3-dimethylbenzene (2a): Representative Procedure. 4-Chloro-2,6-} dimethylphenol (107 g, $0.683 \mathrm{~mol})$ and $\mathrm{K}_{2} \mathrm{CO}_{3}(220 \mathrm{~g}, 1.59 \mathrm{~mol})$ were suspended in $2.5 \mathrm{~L}$ of acetone. Dimethyl sulfate was added and the solution was heated to reflux overnight. The resulting yellow solution was cooled to room temperature and additional dimethyl sulfate $(50 \mathrm{~mL}, 0.52 \mathrm{mmol})$ and $\mathrm{K}_{2} \mathrm{CO}_{3}(50 \mathrm{~g}, 0.36 \mathrm{mmol})$ were added and the reaction mixture was heated to reflux for $4 \mathrm{~h}$. After cooling, the reaction mixture was filtered and the filtrate was evaporated to dryness. The product was carried to the next step without further purification. Yield: $152 \mathrm{~g}(97 \%) .{ }^{1} \mathrm{H}$ NMR $\left(400 \mathrm{MHz}, d_{\sigma^{-}}\right.$ Acetone): $\delta 2.88\left(\mathrm{~s}, 3 \mathrm{H}, \mathrm{OCH}_{3}\right), 3.95\left(\mathrm{~s}, 6 \mathrm{H}, \mathrm{CH}_{3}\right), 7.01(\mathrm{~s}, 2 \mathrm{H}, \mathrm{ArH}) \mathrm{ppm} .{ }^{13} \mathrm{C} \mathrm{NMR}\left(100 \mathrm{MHz}, d_{6^{-}}\right.$ Acetone): $\delta 15.2,58.5,59.1,127.8,132.8,155.8 \mathrm{ppm}$. 
5-Bromo-2-methoxy-1,3-dimethylbenzene (2b). ${ }^{1} \mathrm{H}$ NMR (400 MHz, $d_{6}$-Acetone): $\delta 2.28$ (s, 6H, $\left.\mathrm{CH}_{3}\right), 3.95\left(\mathrm{~s}, 3 \mathrm{H}, \mathrm{OCH}_{3}\right), 7.16(\mathrm{~s}, 2 \mathrm{H}, \mathrm{ArH}) \mathrm{ppm} .{ }^{13} \mathrm{C} \mathrm{NMR}\left(100 \mathrm{MHz}, d_{6}\right.$-Acetone): $\delta$ 16.0, 59.6, $116.4,131.5,133.1,156.2 \mathrm{ppm}$.

ii. 5-Chloro-2-methoxybenzene-1,3-dicarboxylic acid (6a): Representative Procedure. To a solution of $\mathrm{KOH}(9.25 \mathrm{~g}, 165 \mathrm{mmol})$ in $3.5 \mathrm{~L}$ of water was added $63.4 \mathrm{~g}(373 \mathrm{mmol})$ of $2 \mathbf{a}$. The solution was heated to reflux and $\mathrm{KMnO}_{4}(300 \mathrm{~g}, 1.90 \mathrm{~mol})$ was added in $20 \mathrm{~g}$ portions over 7 days. The solution was then filtered and the volume of the filtrate was reduced to $1 \mathrm{~L}$ under vacuum. The filtrate was acidified to $\mathrm{pH} 1$ with conc. $\mathrm{HCl}$ and cooled to $4{ }^{\circ} \mathrm{C}$. The resulting white precipitate was collected by filtration and dried. Yield: $42.8 \mathrm{~g}(50 \%) .{ }^{1} \mathrm{H}$ NMR (400 MHz, $d_{6}$-DMSO): $\delta 3.77$ (s, $3 \mathrm{H}$, $\left.\mathrm{OCH}_{3}\right), 7.79$ (s, 2H, ArH), 13.45 (s, 2H, COOH) ppm. ${ }^{13} \mathrm{C}$ NMR (100 MHz, $d_{6}$-DMSO): $\delta 63.7,127.9$, $130.2,133.1,156.8,166.2 \mathrm{ppm}$.

5-Bromo-2-methoxybenzene-1,3-dicarboxylic acid (6b). ${ }^{1} \mathrm{H}$ NMR (400 MHz, $d_{6}$-DMSO): $\delta 3.77$ (s, 3H, $\mathrm{OCH}_{3}$ ), 7.90 (s, 2H, ArH), 13.43 (s, br, 2H, COOH) ppm. ${ }^{13} \mathrm{C}$ NMR (100 MHz, $\left.d_{6}-\mathrm{DMSO}\right): \delta 63.6$, 115.5, 130.5, 135.9, 157.3, 166.1 ppm. Anal. Calcd. (Found) for $\mathrm{C}_{9} \mathrm{H}_{7} \mathrm{BrO}_{5} \bullet \mathrm{H}_{2} \mathrm{O}$ : C, 36.88 (36.76); H, 3.10 (3.04) ppm.

iii. (2-Hydroxy-5-methoxy-1,3-phenylene)dimethanol (4d): Representative Procedure. To a solution of $\mathrm{NaOH}(80 \mathrm{~g}, 2.0 \mathrm{~mol})$ and 4-methoxyphenol $(124 \mathrm{~g}, 1.0 \mathrm{~mol})$ in water $(1 \mathrm{~L})$ was added paraformaldehyde (90 g) slowly, while stirring, so that the solution temperature did not exceed $40{ }^{\circ} \mathrm{C}$. The reaction mixture was stirred for $24 \mathrm{~h}$ at $30{ }^{\circ} \mathrm{C}$ and was then saturated with sodium sulfate. After standing at $0{ }^{\circ} \mathrm{C}$ overnight, the product precipitated out of solution and was collected by filtration, washed with cold water and air dried. Yield: $144 \mathrm{~g}(78 \%) .{ }^{1} \mathrm{H}$ NMR (500 MHz, $d_{6}$-DMSO): $\delta 3.66$ (s, $\left.3 \mathrm{H}, \mathrm{CH}_{3}\right), 4.50\left(\mathrm{~s}, 4 \mathrm{H}, \mathrm{CH}_{2}\right), 6.729(\mathrm{~s}, 2 \mathrm{H}, \mathrm{ArH}) \mathrm{ppm} .{ }^{13} \mathrm{C} \mathrm{NMR}\left(125 \mathrm{MHz}, d_{6}\right.$-DMSO): $\delta 55.2,59.1$, $110.8,128.4,129.8,144.8,152.4 \mathrm{ppm}$. 
(5-Fluoro-2-hydroxy-1,3-phenylene)dimethanol (4c). ${ }^{1} \mathrm{H} \mathrm{NMR}\left(400 \mathrm{MHz}, \mathrm{CDCl}_{3}\right): \delta 4.51(\mathrm{~d}, 4 \mathrm{H}, J=$ $\left.5 \mathrm{~Hz}, \underline{\mathrm{C}}_{2} \mathrm{OH}\right), 5.29$ (t, $\left.2 \mathrm{H}, J=5 \mathrm{~Hz}, \mathrm{CH}_{2} \mathrm{OH}\right), 6.92(\mathrm{~d}, 2 \mathrm{H}, J=9 \mathrm{~Hz}, \mathrm{ArH}), 8.40$ (s, 1H, ArOH) ppm. ${ }^{13} \mathrm{C}$ NMR $\left(100 \mathrm{MHz}, \mathrm{CDCl}_{3}\right) \delta: 59.0,111.5,111.7,131.3,131.4,147.1 \mathrm{ppm}$. Anal. Calcd. (Found) for $\mathrm{C}_{8} \mathrm{H}_{9} \mathrm{FO}_{3}: \mathrm{C}, 55.81$ (55.95); H, 5.27 (5.42).

iv. (2-(Benzyloxy)-5-fluoro-1,3-phenylene)dimethanol (5c): Representative Procedure. To a solution of $9.0 \mathrm{~g}(52 \mathrm{mmol})$ of $4 \mathrm{c}$ in $150 \mathrm{~mL}$ of DMF was added $9.5 \mathrm{~g}(69 \mathrm{mmol})$ of anhydrous $\mathrm{K}_{2} \mathrm{CO}_{3}$ and $5.5 \mathrm{~mL}(65 \mathrm{mmol})$ of benzyl chloride while stirring. The reaction mixture was stirred overnight at $75{ }^{\circ} \mathrm{C}$ under $\mathrm{N}_{2}$. The resulting yellow slurry was filtered over celite, the filtrate was collected and its volume was reduced. The resulting yellow residue was applied to a silica column and eluted with ethyl acetate. The product, a yellow solid, was recrystallized (ethyl acetate and hexanes). Yield: $9.9 \mathrm{~g}$ (72\%). ${ }^{1} \mathrm{H}$ NMR (400 MHz, $d_{6}$-DMSO): $\delta 4.54$ (d, $\left.4 \mathrm{H}, J=7 \mathrm{~Hz}, \underline{\mathrm{C}}_{2} \mathrm{OH}\right), 4.81$ (s, 2H, $\mathrm{CH}_{2} \mathrm{Ar}$ ), 5.27 (t, $\left.2 \mathrm{H}, J=6 \mathrm{~Hz}, \mathrm{CH}_{2} \mathrm{OH}\right), 7.09(\mathrm{~d}, 2 \mathrm{H}, J=9 \mathrm{~Hz}, \mathrm{ArH}), 7.38(\mathrm{~m}, 5 \mathrm{H}, \mathrm{ArH}) \mathrm{ppm} .{ }^{13} \mathrm{C} \mathrm{NMR}\left(100 \mathrm{MHz}, d_{6^{-}}\right.$ DMSO): $\delta 58.0,75.8,112.9,113.1,128.5,128.5,128.9,137.8,138.2,138.3,149.1$ ppm. MS (FAB+): $m / z 262.1\left[\mathrm{MH}^{+}\right]$

(2-(Benzyloxy)-5-methoxy-1,3-phenylene)dimethanol (5d). ${ }^{1} \mathrm{H}$ NMR $\left(300 \mathrm{MHz}, \mathrm{CDCl}_{3}\right): \delta 2.01(\mathrm{t}$, $\left.2 \mathrm{H}, J=7 \mathrm{~Hz}, \mathrm{CH}_{2} \mathrm{OH}\right), 3.80\left(\mathrm{~s}, 3 \mathrm{H}, \mathrm{OCH}_{3}\right), 4.68\left(\mathrm{~d}, 4 \mathrm{H}, J=10 \mathrm{~Hz}, \mathrm{C}_{2} \mathrm{OH}\right), 4.90\left(\mathrm{~s}, 2 \mathrm{H}, \mathrm{CH}_{2}\right), 6.98(\mathrm{~s}$, $2 \mathrm{H}, \mathrm{ArH}), 7.35-7.45$ (m, 5H, ArH) ppm. ${ }^{13} \mathrm{C}$ NMR (125 MHz, $d_{6}$-DMSO): $\delta 55.2,58.1,75.6,111.8$, $128.0,128.5,136.3,137.7,146.6,155.6 \mathrm{ppm}$.

v. (2-Methoxy-5-methyl-1,3-phenylene)dimethanol (5e). To a solution of $\mathrm{NaOH}(49.4 \mathrm{~g}, 1.23 \mathrm{mmol})$ in $450 \mathrm{~mL}$ of water was added $4 \mathrm{e}(136 \mathrm{~g}, 0.81 \mathrm{mmol})$. Dimethyl sulfate $(79.0 \mathrm{ml}, 838 \mathrm{mmol})$ was added to the resulting brown solution, and the reaction mixture was stirred for $\sim 30 \mathrm{~min}$. The solution was then filtered to remove a brown precipitate, the filtrate was returned to the reaction vessel and additional dimethyl sulfate $(40.0 \mathrm{ml}, 420 \mathrm{mmol})$ was added in $4 \mathrm{~mL}$ aliquots every $5 \mathrm{~min}$. Once the addition was complete, the product, a white precipitate, was collected by filtration and dried. Yield: $104 \mathrm{~g}(87 \%) .{ }^{1} \mathrm{H}$ 
NMR (400 MHz, $d_{6}$-Acetone): $\delta 3.70\left(\mathrm{~s}, 3 \mathrm{H}, \mathrm{CH}_{3}\right), 4.18\left(\mathrm{~s}, 3 \mathrm{H}, \mathrm{OCH}_{3}\right), 4.62\left(\mathrm{~s}, 4 \mathrm{H}, \mathrm{CH}_{2} \mathrm{OH}\right), 7.16(\mathrm{~s}$, $2 \mathrm{H}, \mathrm{ArH}) \mathrm{ppm} .{ }^{13} \mathrm{C} \mathrm{NMR}\left(100 \mathrm{MHz}, d_{6}\right.$-Acetone): $\delta 20.2,58.8,61.7,128.0,132.8,134.5,153.1 \mathrm{ppm}$.

vi. 2-(Benzyloxy)-5-fluorobenzene-1,3-dicarboxylic acid (6c): Representative Procedure. To a solution of $\mathbf{5 c}(4.7 \mathrm{~g}, 17.9 \mathrm{mmol})$ in $50 \mathrm{~mL}$ of acetone was added $20 \mathrm{~mL}$ of Jones Reagent ${ }^{35}$ drop-wise over $1 \mathrm{~h}$. The resulting blue-green solution was stirred at room temperature for an additional $5 \mathrm{~h}$, during which time an insoluble dark blue mixture formed. The acetone was removed under reduced pressure and the resulting reside was dissolved in $150 \mathrm{~mL}$ of water and extracted with ethyl acetate $(3 \times 200 \mathrm{~mL})$. The organic layers were combined and dried over $\mathrm{MgSO}_{4}$. After removal of the solvents and recrystallization $(\mathrm{MeOH})$, the product was obtained as an off-white powder. Yield: $3.22 \mathrm{~g}(63 \%)$. ${ }^{1} \mathrm{H}$ NMR (400 MHz, $d_{6}$-DMSO): $\delta 5.01\left(\mathrm{~s}, 2 \mathrm{H}, \mathrm{CH}_{2} \mathrm{Ar}\right), 7.30(\mathrm{~m}, 5 \mathrm{H}, \mathrm{ArH}), 7.68(\mathrm{~d}, 2 \mathrm{H}, J=8 \mathrm{~Hz}, \mathrm{ArH})$, 13.55 (s, $b r, 1 \mathrm{H}, \mathrm{COO} \underline{\mathrm{H}}) \mathrm{ppm} .{ }^{13} \mathrm{C} \mathrm{NMR}\left(100 \mathrm{MHz}, d_{6}\right.$-DMSO): $\delta 77.6,120.1,120.3,128.4,128.7$, 130.7, 130.7, 137.4, 152.5, 156.3, 166.4 ppm. MS (FAB+): m/z $291.2\left[\mathrm{MH}^{+}\right]$. Anal. Calcd. (Found) for $\mathrm{C}_{15} \mathrm{H}_{11} \mathrm{FO}_{5}$ : C, 62.07 (62.30); H, 3.82 (3.82).

5-Bromo-2-methoxybenzene-1,3-dicarboxylic acid (6d). ${ }^{1} \mathrm{H}$ NMR (500 MHz, $\left.\mathrm{CDCl}_{3}\right): \delta 3.90(\mathrm{~s}, 3 \mathrm{H}$, $\mathrm{CH}_{3}$ ), 5.15 (s, 2H, $\mathrm{ArCH}_{2}$ ), 7.42 (m, 3H, ArH), 7.48 (m, 2H, ArH), 7.84 (s, 2H, ArH) ppm. ${ }^{13} \mathrm{C}$ NMR (125 MHz, $\left.\mathrm{CDCl}_{3}\right): \delta 55.9,77.0,118.2,127.9,128.2,128.2,129.3,137.3,149.3,154.6,166.9$ ppm.

vii. 2-Methoxy-5-methylbenzene-1,3-dicarboxylic acid (6e). A solution of 5 e (55 g, $0.30 \mathrm{mmol})$ and $\mathrm{KOH}(5.0 \mathrm{~g}, 89 \mathrm{mmol})$ in $1.4 \mathrm{~L}$ of water was cooled to $0{ }^{\circ} \mathrm{C}$ in an ice bath. $\mathrm{KMnO}_{4}(131 \mathrm{~g}, 0.82 \mathrm{mmol})$ was added in $\sim 10 \mathrm{~g}$ portions over several hours. Once the addition was complete, the solution was warmed to room temperature and $1 \mathrm{~mL}$ of formaldehyde was added. The solution was then filtered over celite and the filtrate was collected. The volume of the filtrate was reduced under vacuum to $\sim 150 \mathrm{~mL}$ and the solution was acidified to $\mathrm{pH} 1$ with conc. $\mathrm{HCl}$. The resulting white precipitate was collected by filtration and dried. Yield: $52 \mathrm{~g}(67 \%) .{ }^{1} \mathrm{H} \mathrm{NMR}\left(400 \mathrm{MHz}, \mathrm{CD}_{3} \mathrm{OD}\right): \delta 2.41\left(\mathrm{~s}, 3 \mathrm{H}, \mathrm{CH}_{3}\right), 3.91(\mathrm{~s}$, 
$\left.3 \mathrm{H}, \mathrm{OCH}_{3}\right), 7.80(\mathrm{~s}, 2 \mathrm{H}, \mathrm{ArH}) \mathrm{ppm} .{ }^{13} \mathrm{C} \mathrm{NMR}\left(100 \mathrm{MHz}, \mathrm{CD}_{3} \mathrm{OD}\right): \delta 20.6,64.0,128.2,134.9,136.3$ 158.5, 169.2 ppm. Anal. Calcd. (Found) for $\mathrm{C}_{10} \mathrm{H}_{10} \mathrm{O}_{5}$ : C, 57.14 (57.40); H, 4.80 (4.84).

viii. 2-Methoxy-5-nitrobenzene-1,3-dicarboxylic acid (6g). A flask containing 6f (15.0 g, 76.5 mmol) was cooled to $0{ }^{\circ} \mathrm{C}$. A 1:2 mixture of fuming $\mathrm{HNO}_{2}: \mathrm{H}_{2} \mathrm{SO}_{4}(30 \mathrm{~mL}$ total) was added drop-wise over 12 minutes while stirring. The resulting viscous mixture was warmed to room temperature and stirred for 5 $\mathrm{h}$, then poured over crushed ice, causing the product to precipitate out of solution. The solution was filtered and the product washed with cold water. Yield: $13.4 \mathrm{~g}(73 \%) .{ }^{1} \mathrm{H}$ NMR $\left(400 \mathrm{MHz}, d_{6^{-}}\right.$ Acetone): $\delta 4.00\left(\mathrm{~s}, 2 \mathrm{H}, \mathrm{OCH}_{3}\right), 8.66(\mathrm{~s}, 2 \mathrm{H}, \mathrm{ArH}) \mathrm{ppm} .{ }^{13} \mathrm{C} \mathrm{NMR}\left(100 \mathrm{MHz}, d_{6}\right.$-Acetone): $\delta 63.5$, $128.0,129.2,142.4,163.9,164.7 \mathrm{ppm}$.

ix. (2-Methoxy-5-methyl-1,3-phenylene)bis((2-thioxothiazolidin-3-yl)methanone)

(7e):

Representative Procedure. To a solution of $6 \mathbf{e}$ (40 g, $0.19 \mathrm{~mol})$ in $250 \mathrm{~mL}$ of dry dioxane was added $48 \mathrm{~mL}(0.66 \mathrm{~mol})$ of thionyl chloride and 2 drops of DMF. The mixture was heated to reflux and stirred overnight under $\mathrm{N}_{2}$. The volatiles were removed under vacuum by co-evaporation with $50 \mathrm{~mL}$ of dioxane. The crude acyl chloride was dissolved in $200 \mathrm{~mL}$ of $\mathrm{CH}_{2} \mathrm{Cl}_{2}$ and a solution of 2mercaptiothiazoline $(50 \mathrm{~g}, 0.42 \mathrm{~mol})$ and $\mathrm{NEt}_{3}(55 \mathrm{~mL})$ in $100 \mathrm{~mL}$ of $\mathrm{CH}_{2} \mathrm{Cl}_{2}$ was added drop-wise at $78{ }^{\circ} \mathrm{C}$. The reaction mixture was warmed to room temperature and stirred overnight. The resulting yellow reaction mixture was washed with brine $(100 \mathrm{~mL}), 1 \mathrm{M}$ HCL $(100 \mathrm{~mL})$, and $1 \mathrm{M} \mathrm{NaOH}(2 \times 100$ $\mathrm{mL}$ ) successively. The solution was then dried over $\mathrm{MgSO}_{4}$ and evaporated to dryness, yielding the product as a bright yellow solid. Yield: $62.0 \mathrm{~g}(79 \%) .{ }^{1} \mathrm{H}$ NMR $\left(400 \mathrm{MHz}, \mathrm{CDCl}_{3}\right): \delta 2.31(\mathrm{~s}, 3 \mathrm{H}$, $\left.\mathrm{CH}_{3}\right), 3.40\left(\mathrm{t}, 4 \mathrm{H}, J=7 \mathrm{~Hz}, \mathrm{CH}_{2}\right), 3.84\left(\mathrm{~s}, 3 \mathrm{H}, \mathrm{OCH}_{3}\right), 4.56\left(\mathrm{t}, 4 \mathrm{H}, J=7 \mathrm{~Hz}, \mathrm{CH}_{2}\right), 7.22(\mathrm{~s}, 2 \mathrm{H}, \mathrm{ArH})$ ppm. ${ }^{13} \mathrm{C} \mathrm{NMR}\left(100 \mathrm{MHz}, \mathrm{CDCl}_{3}\right): \delta 20.6,29.3,55.8,63.2,128.2,132.5,133.5,152.7,167.4,200.7$ ppm. MS (FAB+): m/z $413\left[\mathrm{MH}^{+}\right]$. 
(5-Chloro-2-methoxy-1,3-phenylene)bis((2-thioxothiazolidin-3-yl)methanone) (7a). ${ }^{1} \mathrm{H}$ NMR (300 $\left.\mathrm{MHz}_{\mathrm{CDCl}}\right): \delta 3.43\left(\mathrm{t}, 4 \mathrm{H}, J=7 \mathrm{~Hz}, \mathrm{CH}_{2}\right), 3.87\left(\mathrm{~s}, 3 \mathrm{H}, \mathrm{OCH}_{3}\right), 4.59\left(\mathrm{t}, 4 \mathrm{H}, J=7 \mathrm{~Hz}, \mathrm{CH}_{2}\right), 7.35(\mathrm{~s}$, 2H, ArH) ppm. MS (FAB+): $m / z, 433\left[\mathrm{MH}^{+}\right]$.

(5-Bromo-2-methoxy-1,3-phenylene)bis((2-thioxothiazolidin-3-yl)methanone) (7b). ${ }^{1} \mathrm{H}$ NMR (400 $\left.\mathrm{MHz}, \mathrm{CDCl}_{3}\right): \delta 1.59\left(\mathrm{~s}, 3 \mathrm{H}, \mathrm{OCH}_{3}\right), 3.42\left(\mathrm{t}, 4 \mathrm{H}, J=7 \mathrm{~Hz}, \mathrm{CH}_{2}\right), 3.84\left(\mathrm{~s}, 3 \mathrm{H}, \mathrm{OCH}_{3}\right), 4.58(\mathrm{t}, 4 \mathrm{H}, J=7$ $\mathrm{Hz}, \mathrm{CH}_{2}$ ), 7.49 (s, 2H, ArH) ppm. ${ }^{13} \mathrm{C} \mathrm{NMR}\left(100 \mathrm{MHz}, \mathrm{CDCl}_{3}\right): \delta 29.8,56.4,62.3,114.1,130.4,133.7$, 153.9, 165.7, 202.8 ppm. Anal. Calcd. (Found) for $\mathrm{C}_{15} \mathrm{H}_{13} \mathrm{BrN}_{2} \mathrm{O}_{3} \mathrm{~S}_{4} \cdot \mathrm{H}_{2} \mathrm{O}$ : C, 37.74 (37.66); H, 2.74 (2.97); N, 5.87 (5.64); S, 26.86 (26.47).

(2-Methoxy-5-nitro-1,3-phenylene)bis((2-thioxothiazolidin-3-yl)methanone) (7g). ${ }^{1} \mathrm{H}$ NMR (400 $\mathrm{MHz}_{\mathrm{CDCl}}$ ): $\delta 3.47\left(\mathrm{t}, 2 \mathrm{H}, J=7 \mathrm{~Hz}, \mathrm{CH}_{2}\right), 3.95\left(\mathrm{~s}, 3 \mathrm{H}, \mathrm{OCH}_{3}\right), 4.63\left(\mathrm{t}, 2 \mathrm{H}, J=7 \mathrm{~Hz}, \mathrm{CH}_{2}\right), 8.19$ (s, 2H, ArH) ppm. MS (FAB+): m/z $444\left[\mathrm{MH}^{+}\right]$. Anal. Calcd. (Found) for $\mathrm{C}_{15} \mathrm{H}_{13} \mathrm{~N}_{3} \mathrm{O}_{5} \mathrm{~S}_{4}: \mathrm{C}, 40.62$ (40.50); H, 2.95 (3.12); N, 9.47 (9.20); S, 28.92 (29.10).

\section{x. (2-(Benzyloxy)-5-fluoro-1,3-phenylene)bis((2-thioxothiazolidin-3-yl)methanone)}

(7c):

Representative Procedure. To a suspension of $6 \mathrm{c}(5.0 \mathrm{~g}, 17 \mathrm{mmol})$ in $100 \mathrm{~mL}$ of dry benzene was added $4.0 \mathrm{~mL}$ (46 mmol) of oxalyl chloride, along with 2 drops of DMF. The off-white slurry was stirred overnight at $50{ }^{\circ} \mathrm{C}$ under $\mathrm{N}_{2}$, during which the reaction mixture became transparent. The benzene was removed under reduced pressure and the resulting brown residue was dried further under vacuum for 5 hours to remove any remaining oxalyl chloride. The crude acyl chloride was dissolved in $100 \mathrm{~mL}$ of dry THF and cooled in an ice bath. A solution of $30 \mathrm{~mL}$ of $\mathrm{NEt}_{3}, 5.12 \mathrm{~g}$ (43 mmol) of 2mercaptothiazoline, and $50 \mathrm{~mL}$ of dry THF was added drop-wise while stirring. The reaction mixture was stirred overnight at room temperature. The resultant yellow slurry was filtered over celite. The yellow filtrate was collected and its volume was reduced. The resulting oil was dissolved in $\mathrm{CH}_{2} \mathrm{Cl}_{2}$ and washed successively with $1 \mathrm{M} \mathrm{HCl}(200 \mathrm{ml})$ and $1 \mathrm{M} \mathrm{KOH}(200 \mathrm{~mL})$. The organic layer was dried over $\mathrm{MgSO}_{4}$, and further purified on a silica column $\left(\mathrm{CH}_{2} \mathrm{Cl}_{2}\right)$. Yield: $4.66 \mathrm{~g}(55 \%) .{ }^{1} \mathrm{H} \mathrm{NMR}(400 \mathrm{MHz}$, $\left.\mathrm{CDCl}_{3}\right): \delta 3.03\left(\mathrm{t}, 4 \mathrm{H}, J=7 \mathrm{~Hz}, \mathrm{CH}_{2}\right), 4.41\left(\mathrm{t}, 4 \mathrm{H}, J=7 \mathrm{~Hz}, \mathrm{CH}_{2}\right), 4.99\left(\mathrm{~s}, 2 \mathrm{H}, J=6 \mathrm{~Hz}, \mathrm{CH}_{2} \mathrm{Ar}\right), 7.18$ 
(s, 1H, ArH), $7.20(\mathrm{~s}, 1 \mathrm{H}, \mathrm{ArH}), 7.38(\mathrm{~m}, 5 \mathrm{H}, \mathrm{ArH}) \mathrm{ppm} .{ }^{13} \mathrm{C} \mathrm{NMR}\left(100 \mathrm{MHz}, \mathrm{CDCl}_{3}\right): \delta 28.9,55.6$ 118.6, 118.9, 127.5, 128.4, 128.7, 130.5, 136.7, 166.0, 200.6 ppm. MS (FAB+): m/z 493.2 [MH $\left.{ }^{+}\right]$.

(2-(Benzyloxy)-5-methoxy-1,3-phenylene)bis((2-thioxothiazolidin-3-yl)methanone) (7d). ${ }^{1} \mathrm{H}$ NMR $\left(500 \mathrm{MHz}_{\mathrm{CDCl}}\right): \delta 2.99\left(\mathrm{t}, 4 \mathrm{H}, J=7 \mathrm{~Hz}, \mathrm{CH}_{2}\right), 3.74\left(\mathrm{~s}, 3 \mathrm{H}, \mathrm{OCH}_{3}\right), 4.32\left(\mathrm{t}, 4 \mathrm{H}, J=7 \mathrm{~Hz}, \mathrm{CH}_{2}\right), 4.90$ $\left(\mathrm{s}, 2 \mathrm{H}, \mathrm{ArCH}_{2}\right), 6.97(\mathrm{~s}, 2 \mathrm{H}, \mathrm{ArH}), 7.2-7.4(\mathrm{~m}, 7 \mathrm{H}, \mathrm{ArH}) \mathrm{ppm} .{ }^{13} \mathrm{C} \mathrm{NMR}\left(125 \mathrm{MHz}, \mathrm{CDCl}_{3}\right): \delta 28.7$ $55.5,55.7,77.3,116.8,127.2,128.0,128.2,128.9,136.4,146.2,155.2,166.4,200.6$ ppm.

xi. 2-(Benzyloxy)-5-fluoro- $N$-methyl-3-(2-thioxothiazolidine-3-carbonyl)benzamide

(8c):

Representative Procedure. To a solution of 7c $(5.0 \mathrm{~g}, 10.2 \mathrm{mmol})$ in $5 \mathrm{~mL}$ of $\mathrm{CH}_{2} \mathrm{Cl}_{2}$ was added a solution of methylamine ( $0.4 \mathrm{~g}$ of a $40 \%$ aq. soln.) in $98: 2 \mathrm{CH}_{2} \mathrm{Cl}_{2}: \mathrm{MeOH}(200 \mathrm{~mL}$ total) via cannula over $48 \mathrm{~h}$. The solvents were removed under reduced pressure and the reaction mixture was dissolved in $100 \mathrm{~mL}$ of $\mathrm{CH}_{2} \mathrm{Cl}_{2}$ and washed with $150 \mathrm{~mL}$ of $1 \mathrm{M} \mathrm{KOH}$. The reaction mixture was evaporated to dryness and applied to a silica column. Unreacted starting material was eluted with $100 \% \mathrm{CH}_{2} \mathrm{Cl}_{2}$, and the product, a thick yellow oil, was eluted with $10 \%$ EtOAc in $\mathrm{CH}_{2} \mathrm{Cl}_{2}$. Yield: $2.20 \mathrm{~g}(87 \%)$. ${ }^{1} \mathrm{H}$ NMR $\left(400 \mathrm{MHz}, \mathrm{CDCl}_{3}\right): \delta 2.84\left(\mathrm{~d}, 3 \mathrm{H}, J=5 \mathrm{~Hz}, \mathrm{NHC}_{3}\right), 3.13\left(\mathrm{t}, 2 \mathrm{H}, J=7 \mathrm{~Hz}, \mathrm{CH}_{2}\right), 4.49(\mathrm{t}, 2 \mathrm{H}, J=7 \mathrm{~Hz}$ $\mathrm{CH}_{2}$ ), 4.92 (s, 2H, $\left.\mathrm{CH}_{2} \mathrm{Ar}\right), 7.13(\mathrm{dd}, 1 \mathrm{H}, J=7,3 \mathrm{~Hz}, \mathrm{ArH}), 7.30(\mathrm{~m}, 5 \mathrm{H}, \mathrm{ArH}), 7.81$ (dd, 1H, $J=7,3$ $\mathrm{Hz}, \mathrm{ArH}) \mathrm{ppm} .{ }^{13} \mathrm{C} \mathrm{NMR}\left(100 \mathrm{MHz}, \mathrm{CDCl}_{3}\right): \delta 26.6,28.7,118.9,119.2,120.4,120.7,128.0,128.9$, 129.0, 129.5, 129.6, 135.6, 150.0, 157.6, 160.1, 164.1, 166.0, 201.4 ppm. MS (FAB+): m/z $405\left[\mathrm{MH}^{+}\right]$.

5-Chloro-2-methoxy- $N$-methyl-3-(2-thioxothiazolidine-3-carbonyl)benzamide (8a). ${ }^{1} \mathrm{H}$ NMR (500 $\mathrm{MHz}_{\mathrm{CDCl}}$ ): $\delta 2.11\left(\mathrm{~s}, 3 \mathrm{H}, \mathrm{ArCH}_{3}\right), 2.77\left(\mathrm{~d}, 3 \mathrm{H}, J=5 \mathrm{~Hz}, \mathrm{NHCH}_{3}\right), 3.24\left(\mathrm{t}, 2 \mathrm{H}, J=7 \mathrm{~Hz}, \mathrm{CH}_{2}\right), 3.62$ (s, 3H, $\mathrm{OCH}_{3}$ ), 4.42 (t, 2H, $J=7 \mathrm{~Hz}, \mathrm{CH}_{2}$ ), 7.03 (dd, 1H, $\left.J=2,1 \mathrm{~Hz}, \mathrm{ArH}\right), 7.35$ (q, 1H, $J=5 \mathrm{~Hz}$, $\mathrm{NHCH}_{3}$ ), 7.65 (dd, $\left.J=2,1 \mathrm{~Hz}, \mathrm{ArH}\right)$ ppm. ${ }^{13} \mathrm{C} \mathrm{NMR}\left(125 \mathrm{MHz}, \mathrm{CDCl}_{3}\right): \delta 20.4,26.6,29.1,55.7,63.0$, 126.6, 128.8, 132.1, 133.9, 134.1, 153.2, 165.4, 167.3, 201.4 ppm.

5-Bromo-2-methoxy- $\boldsymbol{N}$-methyl-3-(2-thioxothiazolidine-3-carbonyl)benzamide (8b). ${ }^{1} \mathrm{H}$ NMR (400 $\mathrm{MHz}, \mathrm{CDCl}_{3}$ ): $\delta 2.98$ (d, $J=5 \mathrm{~Hz}, 3 \mathrm{H}, \mathrm{NHC}_{3}$ ), 3.31 (t, 2H, $J=7 \mathrm{~Hz}, \mathrm{CH}_{2}$ ), $3.81\left(\mathrm{~s}, 3 \mathrm{H}, \mathrm{OCH}_{3}\right), 4.63$ 
(t, $\left.2 \mathrm{H}, J=7 \mathrm{~Hz}, \mathrm{CH}_{2}\right), 7.34$ (s, $\left.1 \mathrm{H}, \mathrm{ArH}\right), 7.46$ (s, $\left.1 \mathrm{H}, \mathrm{ArH}\right), 8.19$ (s, 1H, $\left.\underline{H C H}_{3}\right) \mathrm{ppm} .{ }^{13} \mathrm{C}$ NMR $(100$ $\left.\mathrm{MHz}, \mathrm{CDCl}_{3}\right): \delta 26.9,29.1,55.5,63.3,117.2,128.9,131.1,134.1,136.6,154.4,164.1,165.8$ ppm. MS $(\mathrm{FAB}+) \mathrm{m} / \mathrm{z} 391\left[\mathrm{MH}^{+}\right]$.

2-(Benzyloxy)-5-methoxy- $N$-methyl-3-(2-thioxothiazolidine-3-carbonyl)benzamide (8d). ${ }^{1} \mathrm{H}$ NMR (500 MHz, $\mathrm{CDCl}_{3}$ ): $\delta 2.82$ (dd, 3H, $J=5,3 \mathrm{~Hz}, \mathrm{CH}_{3}$ ), 3.08 (t, 2H, $J=7 \mathrm{~Hz}, \mathrm{CH}_{2}$ ), $3.80\left(\mathrm{~s}, 3 \mathrm{H}, \mathrm{OCH}_{3}\right.$ ), 4.45 (t, 2H, $J=7 \mathrm{~Hz}, \mathrm{CH}_{2}$ ), 4.87 (s, 2H, $\mathrm{ArCH}_{2}$ ), 6.96 (s, 2H, ArH), $7.30-7.45$ (m, 5H, ArH), 7.44 (d, $\left.1 \mathrm{H}, J=5 \mathrm{~Hz}, \mathrm{NHCH}_{3}\right), 7.63$ (s, 2H, ArH) ppm. ${ }^{13} \mathrm{C}$ NMR (125 MHz, $\left.\mathrm{CDCl}_{3}\right): \delta 26.3,28.5,55.5,55.8$, 78.2, 117.5, 118.3, 127.7, 128.2, 128.6, 130.6, 135.7, 147.4, 155.9, 164.9, 166.7, 201.1 ppm. MS $(\mathrm{FAB}+): m / z 417\left[\mathrm{MH}^{+}\right]$.

2-Methoxy- $N, 5$-dimethyl-3-(2-thioxothiazolidine-3-carbonyl)benzamide (8e). ${ }^{1} \mathrm{H}$ NMR $(500 \mathrm{MHz}$, $\left.\mathrm{CDCl}_{3}\right): \delta 2.11\left(\mathrm{~s}, 3 \mathrm{H}, \mathrm{ArCH}_{3}\right), 2.76\left(\mathrm{~d}, 3 \mathrm{H}, J=5 \mathrm{~Hz}, \mathrm{NHC}_{3}\right), 3.23\left(\mathrm{t}, 2 \mathrm{H}, J=7 \mathrm{~Hz}, \mathrm{CH}_{2}\right), 3.62(\mathrm{~s}, 3 \mathrm{H}$, $\left.\mathrm{OCH}_{3}\right), 4.40\left(\mathrm{t}, 2 \mathrm{H}, J=7 \mathrm{~Hz}, \mathrm{CH}_{2}\right), 7.03(\mathrm{dd}, 1 \mathrm{H}, J=2,1 \mathrm{~Hz}, \mathrm{ArH}), 7.39\left(\mathrm{q}, 1 \mathrm{H}, J=5 \mathrm{~Hz}, \mathrm{NHCH}_{3}\right)$, $7.65(\mathrm{dd}, 1 \mathrm{H}, J=2,1 \mathrm{~Hz}, \mathrm{ArH}) \mathrm{ppm} .{ }^{13} \mathrm{C} \mathrm{NMR}\left(125 \mathrm{MHz}, \mathrm{CDCl}_{3}\right): \delta 20.4,26.6,29.1,55.7,63.0$, 126.6, 128.8, 132.1, 133.9, 134.1, 153.2, 165.4, 167.3, 201.4 ppm. MS (FAB+) m/z $325\left[\mathrm{MH}^{+}\right]$.

2-Methoxy- $\boldsymbol{N}$-methyl-3-(2-thioxothiazolidine-3-carbonyl)benzamide (8f). ${ }^{1} \mathrm{H}$ NMR (400 MHz, $\left.\mathrm{CDCl}_{3}\right): \delta 2.76\left(\mathrm{~d}, 3 \mathrm{H}, J=5 \mathrm{~Hz}, \mathrm{NHCH}_{3}\right), 3.38\left(\mathrm{t}, 2 \mathrm{H}, J=8 \mathrm{~Hz}, \mathrm{CH}_{2}\right), 3.80\left(\mathrm{~s}, 3 \mathrm{H}, \mathrm{OCH}_{3}\right), 4.58(\mathrm{t}, 2 \mathrm{H}$, $\left.J=8 \mathrm{~Hz}, \mathrm{CH}_{2}\right), 7.16(\mathrm{t}, 1 \mathrm{H}, J=8 \mathrm{~Hz}, \mathrm{ArH}), 7.34(\mathrm{dd}, 1 \mathrm{H}, J=8,2 \mathrm{~Hz}, \mathrm{ArH}), 7.39\left(\mathrm{~m}, b r, 1 \mathrm{H}, \mathrm{NHCH}_{3}\right)$, $8.04(\mathrm{dd}, 1 \mathrm{H}, J=8,2 \mathrm{~Hz}, \mathrm{ArH}) \mathrm{ppm} . \mathrm{MS}(\mathrm{FAB}+): m / z, 311\left[\mathrm{MH}^{+}\right]$.

2-Methoxy- $N$-methyl-5-nitro-3-(2-thioxothiazolidine-3-carbonyl)benzamide $(8 g) . \quad{ }^{1} \mathrm{H}$ NMR (500 $\mathrm{MHz}_{\mathrm{CDCl}}$ ): $\delta 3.01\left(\mathrm{~d}, 3 \mathrm{H}, J=5 \mathrm{~Hz}, \mathrm{NHCH}_{3}\right), 3.49\left(\mathrm{t}, 2 \mathrm{H}, J=7 \mathrm{~Hz}, \mathrm{CH}_{2}\right), 3.96\left(\mathrm{~s}, 3 \mathrm{H}, \mathrm{OCH}_{3}\right), 4.68$ (t, 2H, J= $\left.7 \mathrm{~Hz}, \mathrm{CH}_{2}\right), 7.26(\mathrm{~s}, 1 \mathrm{H}, \mathrm{NH}), 8.18(\mathrm{~d}, 1 \mathrm{H}, J=3 \mathrm{~Hz}, \mathrm{ArH}), 8.87(\mathrm{~d}, 1 \mathrm{H}, J=3 \mathrm{~Hz}, \mathrm{ArH}) \mathrm{ppm}$. ${ }^{13} \mathrm{C}$ NMR (125 MHz, $\left.\mathrm{CDCl}_{3}\right): \delta 27.0,29.0,55.4,65.1,126.4,128.1,128.9,129.5,142.0,159.6,163.5$, 165.2, 201.8 ppm. MS (FAB+): $m / z, 356\left[\mathrm{MH}^{+}\right]$. Anal. Calcd. (Found) for $\mathrm{C}_{13} \mathrm{H}_{13} \mathrm{~N}_{3} \mathrm{O}_{5} \mathrm{~S}_{2}: \mathrm{C}, 43.93$ (44.12); H, 3.69 (3.95); N, 11.82 (11.77); S, 18.05 (18.06). 
Representative Procedure. To a solution of $8 \mathbf{b}(6.5 \mathrm{~g}, 17 \mathrm{mmol})$ in $150 \mathrm{~mL}$ of $\mathrm{CH}_{2} \mathrm{Cl}_{2}, 1,5$ diaminopentane $(0.75 \mathrm{~g}, 7.3 \mathrm{mmol})$ in $100 \mathrm{~mL}$ of $\mathrm{CH}_{2} \mathrm{Cl}_{2}$ was added drop-wise over $12 \mathrm{~h}$. The solution was stirred overnight. The solvents were removed under vacuum and the resulting residue was applied to a silica gel column. The product, a white solid, was eluted with $5 \% \mathrm{MeOH}$ in $\mathrm{CH}_{2} \mathrm{Cl}_{2}$. Yield: $3.3 \mathrm{~g}$ (74\%). ${ }^{1} \mathrm{H}$ NMR (400 MHz, $\left.\mathrm{CDCl}_{3:}\right): \delta 1.47\left(\mathrm{~m}, 2 \mathrm{H}, \mathrm{CH}_{2}\right), 1.66\left(\mathrm{q}, 4 \mathrm{H}, J=7 \mathrm{~Hz}, \mathrm{CH}_{2}\right), 2.99(\mathrm{~d}, 6 \mathrm{H}, J$ $\left.=5 \mathrm{~Hz}, \mathrm{NHCH}_{3}\right) 3.45\left(\mathrm{td}, 4 \mathrm{H}, J=7,6 \mathrm{~Hz}, \mathrm{CH}_{2}\right), 3.81\left(\mathrm{~s}, 6 \mathrm{H}, \mathrm{OCH}_{3}\right), 7.32\left(\mathrm{q}, 2 \mathrm{H}, J=5 \mathrm{~Hz}, \mathrm{NHCH}_{3}\right)$, $7.43(\mathrm{t}, 2 \mathrm{H}, J=6 \mathrm{~Hz}, \mathrm{NH}) 8.03(\mathrm{~s}, 2 \mathrm{H}, \mathrm{ArH}), 8.08(\mathrm{~s}, 2 \mathrm{H}, \mathrm{ArH}) \mathrm{ppm} .{ }^{13} \mathrm{C} \mathrm{NMR}\left(100 \mathrm{MHz}, \mathrm{CDCl}_{3}\right): \delta$ 24.2, 26.9, 29.1, 39.7, 63.5, 118.2, 129.8, 136.6, 154.6, 163.8, 164.4 ppm. MS (FAB+): $m / z 643\left[\mathrm{MH}^{+}\right]$. Anal. Calcd. (Found) for $\mathrm{C}_{25} \mathrm{H}_{30} \mathrm{Br}_{2} \mathrm{~N}_{4} \mathrm{O}_{6}$ : C, 46.75 (46.66); H, 4.71 (4.65); N, 8.72 (8.91).

$N^{1}, N^{11}$-(pentane-1,5-diyl)bis(5-chloro-2-methoxy- $N^{3}$-methylbenzene-1,3-dicarbamide) (9a). $\quad{ }^{1} \mathrm{H}$ NMR (400 MHz, CDCl $): \delta 1.50\left(\mathrm{~m}, 2 \mathrm{H}, \mathrm{CH}_{2}\right), 1.67$ (p, 4H, $\left.J=7 \mathrm{~Hz}, \mathrm{CH}_{2}\right), 2.90(\mathrm{~d}, 6 \mathrm{H}, J=4 \mathrm{~Hz}$, $\mathrm{NHC}_{3}$ ), 3.86 (s, 6H, OCH$\left.)_{3}\right), 7.72$ (d, $\left.1 \mathrm{H}, J=3 \mathrm{~Hz}, \mathrm{ArH}\right), 7.76$ (d, $\left.1 \mathrm{H}, J=3 \mathrm{~Hz}, \mathrm{ArH}\right), 7.81$ (m, 4H, Nㅂ) $)$ ppm. MS (FAB+): m/z $553\left[\mathrm{MH}^{+}\right]$

$N^{1}, N^{1}$-(pentane-1,5-diyl)bis(2-(benzyloxy)-5-fluoro- $N^{3}$-methylbenzene-1,3-dicarbamide) (9c). ${ }^{1} \mathrm{H}$ NMR (400 MHz, $d_{6}$-DMSO): $\delta 1.24$ (m, 2H, $\left.\mathrm{CH}_{2}\right), 1.38$ (m, 4H, $\mathrm{CH}_{2}$ ), $2.74\left(\mathrm{~d}, 6 \mathrm{H}, J=4 \mathrm{~Hz}, \mathrm{NHCH}_{3}\right.$ ), 3.14 (m, 4H, $\left.\mathrm{CH}_{2}\right), 4.95$ (s, 4H, $\left.\mathrm{CH}_{2}\right), 7.35$ (m, 14H, ArH), 8.77 (m, 4H, NH) ppm. ${ }^{13} \mathrm{C}$ NMR (100 MHz, $d_{6}$-DMSO): $\delta 24.0,26.1,28.6,77.3,116.8,117.0,128.2,128.3,133.3,133.4,136.4,149.1,164.5$, $165.0 \mathrm{ppm}$. MS (FAB+): m/z $637\left[\mathrm{MH}^{+}\right]$.

$N^{1}, N^{1}$-(pentane-1,5-diyl)bis(2-(benzyloxy)-5-methoxy- $N^{3}$-methylbenzene-1,3-dicarbamide) (9d). ${ }^{1} \mathrm{H}$ NMR (500 MHz, $\mathrm{CDCl}_{3}$ ): $\delta 1.26$ (q, 2H, $J=4 \mathrm{~Hz}, \mathrm{CH}_{2}$ ), 2.08 (q, $2 \mathrm{H}, J=4 \mathrm{~Hz}, \mathrm{CH}_{2}$ ), 2.78 (d, 3H, $J$ $\left.=3 \mathrm{~Hz}, \mathrm{CH}_{3}\right), 3.32$ (q, $\left.2 \mathrm{H}, J=4 \mathrm{~Hz}, \mathrm{CH}_{2}\right), 3.79\left(\mathrm{~s}, 6 \mathrm{H}, \mathrm{CH}_{3}\right), 4.84\left(\mathrm{~s}, 4 \mathrm{H}, \mathrm{CH}_{2}\right), 7.30$ (d, $4 \mathrm{H}, J=4 \mathrm{~Hz}$, ArH), 7.35 - 7.38 (m, 8H, ArH), 7.47 (t, 2H, $J=7 \mathrm{~Hz}, \mathrm{NH}), 7.53$ (q, 4H, $J=2$, ArH) ppm. ${ }^{13} \mathrm{C}$ NMR (125 MHz, $\left.\mathrm{CDCl}_{3}\right): \delta$ 24.2, 26.5, 28.9, 39.7, 55.8, 79.2, 118.66, 118.9, 128.5, 128.9, 129.1, 129.3, 
129.4, 135.1, 147.6, 156.1, 164.9, 165.5 ppm. MS (FAB+): m/z $697\left[\mathrm{MH}^{+}\right]$.

$N^{1}, N^{1}$-(pentane-1,5-diyl)bis(2-methoxy- $N^{3}, 5$-dimethylbenzene-1,3-dicarbamide) (9e). ${ }^{1} \mathrm{H} \quad \mathrm{NMR}$ (300 MHz, $\mathrm{CDCl}_{3}$ ): $\delta 1.50$ (q, 2H, $J=5 \mathrm{~Hz}, \mathrm{CH}_{2}$ ), 1.64 (q, 2H, $J=5 \mathrm{~Hz}, \mathrm{CH}_{2}$ ), 2.30, (s, 6H, $\mathrm{ArCH}_{3}$ ), 3.39 (d, 3H, $J=4 \mathrm{~Hz}, \mathrm{CH}_{3}$ ), 3.32 (q, 2H, $J=5 \mathrm{~Hz}, \mathrm{CH}_{2}$ ), 3.80 (s, 6H, $\left.\mathrm{CH}_{3}\right), 7.59$ (s, 2H, $\left.\mathrm{ArH}\right), 7.61$ (s, 2H, ArH), 7.73 (s, 2H, NH), 7.78 (s, 2H, ArH) ppm. ${ }^{13} \mathrm{C}$ NMR (75 MHz, $\left.\mathrm{CDCl}_{3}\right): \delta$ 19.7, 24.2, 25.8, 39.2, 62.7, 129.0, 129.3, 132.8, 133.6, 153.7, 165.0 ppm. MS (FAB+): m/z 513 [MH ${ }^{+}$. Anal. Calcd. (Found) for $\mathrm{C}_{27} \mathrm{H}_{36} \mathrm{~N}_{6} \mathrm{O}_{6}$ : C, 63.26 (63.11); H, 7.08 (7.04); N, 10.93 (10.86).

$N^{1}, N^{1}$-(pentane-1,5-diyl)bis(2-methoxy- $N^{3}$-methylbenzene-1,3-dicarbamide) (9f). ${ }^{1} \mathrm{H}$ NMR (500 $\mathrm{MHz}, \mathrm{CDCl}_{3}$ ): $\delta 1.49$ (q, 2H, $J=8 \mathrm{~Hz}, \mathrm{CH}_{2}$ ), 1.69 (q, 4H, $J=8 \mathrm{~Hz}, \mathrm{CH}_{2}$ ), 3.02 (d, 6H, $J=5 \mathrm{~Hz}, \mathrm{CH}_{3}$ ), 3.48 (q, 4H, $J=7 \mathrm{~Hz}, \mathrm{CH}_{2}$ ), $3.82\left(\mathrm{~s}, 6 \mathrm{H}, \mathrm{CH}_{3}\right), 7.25$ (t, 2H, $\left.J=8 \mathrm{~Hz}, \operatorname{ArH}\right), 7.31$ (q, 2H, $J=6 \mathrm{~Hz}$, $\mathrm{NHCH}_{3}$ ), 7.46 (t, 2H, $J=6 \mathrm{~Hz}, \mathrm{NHCH}_{2}$ ), 7.98 (dd, 2H, $\left.J=8,2 \mathrm{~Hz}, \operatorname{ArH}\right), 8.02$ (dd, $2 \mathrm{H}, J=8,2 \mathrm{~Hz}$, ArH) ppm. ${ }^{13} \mathrm{C}$ NMR (125 MHz, $\left.\mathrm{CDCl}_{3}\right): \delta 24.5,26.0,28.4,38.9,62.3,123.7,127.5,127.7,132.5$, 132.5, 155.0, 164.8, 165.4 ppm. MS (FAB+): m/z $485\left[\mathrm{MH}^{+}\right]$.

$N^{1}, N^{1}$-(pentane-1,5-diyl)bis(2-methoxy- $N^{3}$-methyl-5-nitrobenzene-1,3-dicarbamide) (9g). $\quad{ }^{1} \mathrm{H}$ NMR (400 MHz, CDCl $): \delta 1.52\left(\mathrm{~m}, 2 \mathrm{H}, \mathrm{CH}_{2}\right), 1.69$ (q, 4H, $\left.J=7 \mathrm{~Hz}, \mathrm{CH}_{2}\right), 2.93(\mathrm{~d}, 6 \mathrm{H}, J=5 \mathrm{~Hz}$, $\left.\mathrm{NHCH}_{3}\right), 4.02$ (s, 6H, OCH$)_{3}, 8.00$ (m, 4H, NH), 8.50 (d, 2H, $\left.J=3 \mathrm{~Hz}, \mathrm{ArH}\right), 8.55$ (d, 2H, $J=7 \mathrm{~Hz}$, ArH) ppm. MS (FAB+): m/z $575\left[\mathrm{MH}^{+}\right]$.

$N^{1}, N^{1}$-(pentane-1,5-diyl)bis(2-methoxy- $N^{3}, N^{5}$-dimethylbenzene-1,3,5-tricarboxamide) (9h). ${ }^{1} \mathrm{H}$ NMR (500 MHz, $\left.\mathrm{CDCl}_{3}\right): \delta 1.40$ (q, 2H, $\left.J=8 \mathrm{~Hz}, \mathrm{CH}_{2}\right), 1.56\left(\mathrm{q}, 4 \mathrm{H}, J=8 \mathrm{~Hz}, \mathrm{CH}_{2}\right), 2.75(\mathrm{~d}, 6 \mathrm{H}, J=5$ $\left.\mathrm{Hz}, \mathrm{CH}_{3}\right), 2.78\left(\mathrm{~d}, 6 \mathrm{H}, J=5 \mathrm{~Hz}, \mathrm{CH}_{3}\right), 3.26$ (q, 2H, $\left.J=7 \mathrm{~Hz}, \mathrm{CH}_{2}\right), 3.79\left(\mathrm{~s}, 6 \mathrm{H}, \mathrm{CH}_{3}\right), 7.98(\mathrm{~d}, 4 \mathrm{H}, J=3$ $\mathrm{Hz}, \operatorname{ArH}), 8.02$ (d, 4H, $J=3 \mathrm{~Hz}, \operatorname{ArH}), 8.31$ (q, 2H, $\left.J=7 \mathrm{~Hz}, \mathrm{NHCH}_{3}\right), 8.39$ (t, 2H, $J=6 \mathrm{~Hz}, \mathrm{NHCH}_{2}$ ), 8.55 (q, 2H, $J=5 \mathrm{~Hz}, \mathrm{NHCH}_{3}$ ) ppm. $\left.{ }^{13} \mathrm{C} \mathrm{NMR} \mathrm{(125} \mathrm{MHz,} \mathrm{CDCl}_{3}\right): \delta 23.9,25.5,26.3,26.4,28.7,62.1$, 62.2, 129.1, 129.7, 129.7, 130.0, 130.5, 156.7, 165.1, 165.5, 166.0 ppm. MS (FAB+): m/z 599.3 [MH ${ }^{+}$. xiii. $N^{1}, N^{1}$-(pentane-1,5-diyl)bis(2-hydroxy- $N^{3}, N^{5}$-dimethylbenzene-1,3,5-tricarboxamide) - 5LIIAM-(C=O) $\mathbf{N H C H}_{3}$ (10h): Representative Procedure. To a solution of $9 \mathrm{~h}$ in $30 \mathrm{~mL}$ of $\mathrm{CH}_{2} \mathrm{Cl}_{2}$ 
cooled in an acetone/dry ice bath was added $2.0 \mathrm{~mL}$ (22.8 mmol) of $\mathrm{BBr}_{3}$ with a syringe while stirring. The reaction mixture was warmed to room temperature and was stirred for 64 hours. The progress of the reaction was monitored with ${ }^{1} \mathrm{H}$ NMR. Once the reaction was complete, the volatiles were removed under vacuum. The resulting off-white residue was dissolved in $10 \mathrm{~mL}$ of $\mathrm{MeOH}$. The MeOH solution was diluted with $40 \mathrm{~mL}$ of water and heated until a transparent solution was obtained and the volume had been reduced to $\sim 10 \mathrm{~mL}$. Upon cooling the product precipitated out of solution and was collected by filtration and dried. Yield: 70\%. ${ }^{1} \mathrm{H}$ NMR (500 MHz, $d_{6}$-DMSO): $\delta 1.37$ (q, $2 \mathrm{H}, J=7 \mathrm{~Hz}, \mathrm{CH}_{2}$ ), 1.58 (q, 4H, $J=7.0 \mathrm{~Hz}, \mathrm{CH}_{2}$ ), 2.76 (d, 6H, $J=5 \mathrm{~Hz}, \mathrm{CH}_{3}$ ), 2.82 (d, 6H, $\left.J=5 \mathrm{~Hz}, \mathrm{CH}_{3}\right), 3.31$ (q, 4H, $J=$ 7, $\left.\mathrm{CH}_{2}\right), 8.84\left(\mathrm{~m}, \mathrm{br}, 4 \mathrm{H}+2 \mathrm{H}, \mathrm{ArH}+\mathrm{NHCH}_{2}\right), 8.80\left(\mathrm{q}, 2 \mathrm{H}, J=5 \mathrm{~Hz}, \mathrm{NHCH}_{3}\right), 8.86(\mathrm{q}, 2 \mathrm{H}, J=5 \mathrm{~Hz}$, $\mathrm{NHCH}_{3}$ ) ppm. MS (FAB+): m/z $571\left[\mathrm{MH}^{+}\right]$. Anal. Calcd. (Found) for $\mathrm{C}_{27} \mathrm{H}_{34} \mathrm{~N}_{6} \mathrm{O}_{8} \bullet 4 \mathrm{H}_{2} \mathrm{O}: \mathrm{C}, 50.46$ (50.38); H, 6.58 (6.28); N, 13.07 (13.09).

$N^{1}, N^{1}$-(pentane-1,5-diyl)bis(5-chloro-2-hydroxy- $N^{3}$-methylbenzene-1,3-dicarbamide) - 5LI-IAMCl (10a). ${ }^{1} \mathrm{H}$ NMR (400 MHz, $d_{6}$-DMSO): $\delta 1.40\left(\mathrm{~m}, 2 \mathrm{H}, \mathrm{CH}_{2}\right), 1.60\left(\mathrm{~m}, 4 \mathrm{H}, \mathrm{CH}_{2}\right), 2.82(\mathrm{~d}, 6 \mathrm{H}, J=4$

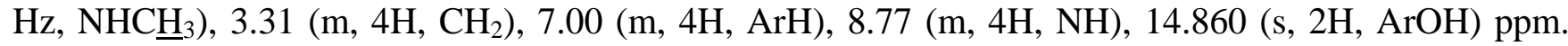
MS (FAB+): m/z $525\left[\mathrm{MH}^{+}\right]$. Anal. Calcd. (Found) for $\mathrm{C}_{23} \mathrm{H}_{26} \mathrm{Cl}_{2} \mathrm{~N}_{4} \mathrm{O}_{6}$ : C, 52.58 (52.30); H, 4.99 (4.88); N, 10.66 (10.47).

$N^{1}, N^{1}$-(pentane-1,5-diyl)bis(5-bromo-2-hydroxy- $N^{3}$-methylbenzene-1,3-dicarbamide) - 5LI-IAMBr (10b). ${ }^{1} \mathrm{H}$ NMR (300 MHz, $d_{6}$-DMSO): $\delta 1.40$ (m, 2H, $\left.\mathrm{CH}_{2}\right), 1.56\left(\mathrm{~m}, 4 \mathrm{H}, \mathrm{CH}_{2}\right), 2.81(\mathrm{~d}, 6 \mathrm{H}, J=5$

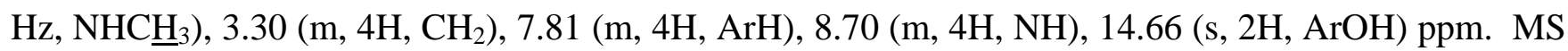
(FAB+): m/z $613\left[\mathrm{MH}^{+}\right]$. Anal. Calcd. (Found) for $\mathrm{C}_{23} \mathrm{H}_{26} \mathrm{Br}_{2} \mathrm{~N}_{4} \mathrm{O}_{6}$ : C, 44.97 (44.73); H, 4.27 (4.47); N, $9.12(8.81)$.

$N^{1}, N^{1}$-(pentane-1,5-diyl)bis(2-hydroxy- $N^{3}, 5$-dimethylbenzene-1,3-dicarbamide) - 5LI-IAM-CH (10e). ${ }^{1} \mathrm{H}$ NMR (400 MHz, $d_{6}$-DMSO): $\delta 1.45\left(\mathrm{~m}, 2 \mathrm{H}, \mathrm{CH}_{2}\right), 1.61\left(\mathrm{~m}, 4 \mathrm{H}, \mathrm{CH}_{2}\right), 2.82(\mathrm{~d}, 6 \mathrm{H}, J=4 \mathrm{~Hz}$, $\left.\mathrm{NHCH}_{3}\right), 3.29\left(\mathrm{~m}, 4 \mathrm{H}, \mathrm{CH}_{2} \mathrm{~N}\right), 7.79(\mathrm{~m}, 4 \mathrm{H}, \mathrm{ArH}), 8.77(\mathrm{~m}, 4 \mathrm{H}, \mathrm{NH}), 14.65(\mathrm{~s}, 2 \mathrm{H}, \mathrm{ArOH}) \mathrm{ppm} . \mathrm{MS}$ 
(FAB+): $m / z 485\left[\mathrm{MH}^{+}\right]$. Anal. Calcd. (Found) for $\mathrm{C}_{25} \mathrm{H}_{32} \mathrm{~N}_{4} \mathrm{O}_{6} \cdot \mathrm{H}_{2} \mathrm{O}: \mathrm{C}, 59.75$ (59.81); H, 6.82 (6.82);

N, 11.15 (11.08).

$N^{1}, N^{1}$-(pentane-1,5-diyl)bis(2-hydroxy- $N^{3}$-methylbenzene-1,3-dicarbamide) - 5LI-IAM-H (10f). ${ }^{1} \mathrm{H}$ NMR (500 MHz, $d_{6}$-DMSO): $\delta 1.36\left(\mathrm{q}, 2 \mathrm{H}, J=8, \mathrm{CH}_{2}\right), 1.57\left(\mathrm{q}, 4 \mathrm{H}, J=8, \mathrm{CH}_{2}\right), 2.81(\mathrm{~d}, 6 \mathrm{H}, J=5$, $\left.\mathrm{CH}_{3}\right), 3.30\left(\mathrm{q}, 4 \mathrm{H}, J=7, \mathrm{CH}_{2}\right), 3.82\left(\mathrm{~s}, 6 \mathrm{H}, \mathrm{CH}_{2}\right), 6.95(\mathrm{t}, 2 \mathrm{H}, J=8 \mathrm{~Hz}, \mathrm{ArH}), 7.31(\mathrm{dd}, 4 \mathrm{H}, J=8,2 \mathrm{~Hz}$ ArH), 7.46 (m, 4H, NH) ppm. MS (FAB+): m/z $457 \quad\left[\mathrm{MH}^{+}\right]$. Anal. Calcd. (Found) for $\mathrm{C}_{23} \mathrm{H}_{28} \mathrm{~N}_{4} \mathrm{O}_{6} \cdot \mathrm{H}_{2} \mathrm{O}: \mathrm{C}, 58.22$ (58.34); H, 6.37 (6.59); N, 11.81 (11.78).

$N^{1}, N^{1}$-(pentane-1,5-diyl)bis(2-hydroxy- $N^{3}$-methyl-5-nitrobenzene-1,3-dicarbamide) 5LI-IAMNO N10g). $^{1} \mathrm{H}$ NMR (300 MHz, $d_{6}$-DMSO): $\delta 1.40$ (m, 2H, $\left.\mathrm{CH}_{2}\right), 1.60\left(\mathrm{~m}, 4 \mathrm{H}, \mathrm{CH}_{2}\right), 2.82(\mathrm{~d}, 6 \mathrm{H}, J=4$ $\left.\mathrm{Hz}, \mathrm{NHC}_{3}\right), 3.34\left(\mathrm{~m}, 4 \mathrm{H}, \mathrm{CH}_{2} \mathrm{~N}\right), 8.82$ (m, 4H, ArH), 9.30 (m, br, 4H, NH) ppm. MS (FAB+): m/z $547\left[\mathrm{MH}^{+}\right]$. Anal. Calcd. (Found) for $\mathrm{C}_{23} \mathrm{H}_{26} \mathrm{~N}_{6} \mathrm{O}_{10} \cdot \mathrm{H}_{2} \mathrm{O}$ : C, 49.13 (48.94); H, 5.00 (4.81); N, 14.89 (15.10).

xiv. $N^{1}, N^{1}$-(pentane-1,5-diyl)bis(5-fluoro-2-hydroxy- $N^{3}$-methylbenzene-1,3-dicarbamide) - 5LIIAM-F (10c). To a solution of $9 \mathbf{c}(2.0 \mathrm{~g}, 2.97 \mathrm{mmol})$ in $25 \mathrm{~mL}$ of acetic acid was added $25 \mathrm{~mL}$ of conc. $\mathrm{HCl}$ and the reaction mixture was stirred for $48 \mathrm{~h}$ at room temperature. A white precipitate formed, and was collected by filtration and dried. The filtrate was reduced in volume and a second crop of product was collected. Yield: $1.24 \mathrm{~g}(85 \%) .{ }^{1} \mathrm{H}$ NMR (400 MHz, $d_{6}$-DMSO): $\delta 1.37\left(\mathrm{~m}, 2 \mathrm{H}, \mathrm{CH}_{2}\right), 1.56(\mathrm{~m}$, 4H, $\left.\mathrm{CH}_{2}\right), 2.82\left(\mathrm{~d}, 6 \mathrm{H}, J=4 \mathrm{~Hz}, \mathrm{NHC}_{3}\right), 3.29\left(\mathrm{~m}, 4 \mathrm{H}, \mathrm{CH}_{2}\right), 7.79(\mathrm{~m}, 4 \mathrm{H}, \mathrm{ArH}), 8.77(\mathrm{~m}, b r, 4 \mathrm{H}, \mathrm{NH})$, 14.65 (s, 2H, ArOH) ppm. ${ }^{13} \mathrm{C}$ NMR (100 MHz, $d_{6}$-DMSO): $\delta 23.6,26.2,28.3,118.4,118.7,119.3$ 119.4, 152.4, 154.8, 155.8, 165.9, 166.33 ppm. MS (FAB+): $m / z 493\left[\mathrm{MH}^{+}\right]$. Anal. Calcd. (Found) for $\mathrm{C}_{23} \mathrm{H}_{26} \mathrm{~F}_{2} \mathrm{~N}_{4} \mathrm{O}_{6}: \mathrm{C}, 56.06$ (55.84); H, 5.32 (5.31); N, 11.38 (11.40).

xv. $N^{1}, N^{1}$-(pentane-1,5-diyl)bis(2-hydroxy-5-methoxy- $N^{3}$-methylbenzene-1,3-dicarbamide) - 5LIIAM-OCH $\mathbf{3}(\mathbf{1 0 d})$. To a solution of $9 \mathbf{d}(0.35 \mathrm{~g}, 0.5 \mathrm{mmol})$ in $25 \mathrm{~mL}$ of a 1:1 mixture of glacial acetic acid and $\mathrm{MeOH}$ was added $0.1 \mathrm{~g}$ of $\mathrm{Pd} / \mathrm{C}$ catalyst (palladium, $10 \mathrm{wt}$. \% on activated carbon). The 
mixture was hydrogenated (atmospheric pressure, room temperature) overnight. The catalyst was removed by filtration, and the filtrate was evaporated to dryness to give the product as a beige solid. Yield: $0.22 \mathrm{~g}(85 \%) .{ }^{1} \mathrm{H}$ NMR $\left(500 \mathrm{MHz}, \mathrm{DMSO}-d_{6}\right): \delta 1.35\left(\mathrm{q}, 2 \mathrm{H}, J=8 \mathrm{~Hz}, \mathrm{CH}_{2}\right), 1.57(\mathrm{q}, 4 \mathrm{H}, J=$ $\left.7 \mathrm{~Hz}, \mathrm{CH}_{2}\right), 2.81\left(\mathrm{~d}, 6 \mathrm{H}, J=5 \mathrm{~Hz}, \mathrm{CH}_{3}\right), 3.30\left(\mathrm{q}, 4 \mathrm{H}, J=7 \mathrm{~Hz}, \mathrm{CH}_{2}\right), 3.74\left(\mathrm{~s}, 6 \mathrm{H}, \mathrm{OCH}_{3}\right), 7.29(\mathrm{dd}, 4 \mathrm{H}$, $J=6,3 \mathrm{~Hz}, \mathrm{ArH}), 8.77(\mathrm{~m}, 4 \mathrm{H}, \mathrm{NH}) \mathrm{ppm} .{ }^{13} \mathrm{C} \mathrm{NMR}\left(500 \mathrm{MHz}, \mathrm{CDCl}_{3}\right): \delta 23.9,26.2,28.5,55.9$ 117.7, 117.9, 118.6, 118.8, 150.7, 153.6, 166.6, 167.3 ppm. MS (FAB+): $m / z 517\left[\mathrm{MH}^{+}\right]$.

xvi: $\quad$ 5,5'-(pentane-1,5-diylbis(azanediyl))bis(oxomethylene)bis(4-hydroxy-3-(methylcarbamoyl) benzenesulfonic acid) - 5LI-IAM-SO $3 \mathbf{H}(\mathbf{1 0 i})$. 9f (474 mg, $1 \mathrm{mmol}$ ) was dissolved in $30 \%$ fuming sulfuric acid $(10 \mathrm{~mL})$ while stirring in a $25 \mathrm{~mL}$ round bottom flask. After being stirred for $18 \mathrm{~h}$, the reaction mixture was poured onto crushed ice $(20 \mathrm{~g})$ while being cooled in an ice/ $\mathrm{NaCl}$ bath causing the product to precipitate out of solution. The product was collected by filtration and washed successively with cold $\mathrm{MeOH}$ and $\mathrm{Et}_{2} \mathrm{O}$. Yield: $510 \mathrm{mg}(81 \%)$. ${ }^{1} \mathrm{H}$ NMR (500 MHz, $d_{6}$-DMSO): $\delta 1.35$ (q, $2 \mathrm{H}, J=$ $\left.7 \mathrm{~Hz}, \mathrm{CH}_{2}\right), 1.57\left(\mathrm{q}, 4 \mathrm{H}, J=7 \mathrm{~Hz}, \mathrm{CH}_{2}\right), 2.80\left(\mathrm{~d}, 6 \mathrm{H}, J=5 \mathrm{~Hz}, \mathrm{CH}_{3}\right), 3.28\left(\mathrm{q}, 4 \mathrm{H}, J=6 \mathrm{~Hz}, \mathrm{CH}_{2}\right), 8.25$ $(\mathrm{d}, 4 \mathrm{H}, J=10 \mathrm{~Hz}, \mathrm{ArH}), 8.79(\mathrm{~s}, 2 \mathrm{H}, \mathrm{ArH}), 8.96(\mathrm{~m}, 2 \mathrm{H}, \mathrm{NH}) \mathrm{ppm} .{ }^{13} \mathrm{C} \mathrm{NMR}\left(100 \mathrm{MHz}, \mathrm{D}_{2} \mathrm{O}\right): \delta 23.4$ $25.9,27.9,39.3,115.5,118.1,128.6,130.3,133.3,160.5,166.4,167.6$ ppm. MS (FAB+): $m / z 617$ $\left[\mathrm{MH}^{+}\right]$. Anal. Calcd. (Found) for $\mathrm{C}_{23} \mathrm{H}_{28} \mathrm{~N}_{4} \mathrm{O}_{12} \mathrm{~S}_{2} \bullet \mathrm{H}_{2} \mathrm{O}: \mathrm{C}$ 43.53(43.90); H 4.76(4.81); N 8.83 (8.74); S $10.11(9.72)$

\section{General Procedure for the Synthesis of Gd(III) Complexes}

To a solution of $0.05 \mathrm{mmol}$ of ligand in $10 \mathrm{~mL}$ of $\mathrm{MeOH}$ was added $1.25 \mathrm{~mL}$ of a $20 \mathrm{mM}$ solution $(0.025 \mathrm{mmol})$ of $\mathrm{GdCl}_{3} \cdot 6 \mathrm{H}_{2} \mathrm{O} .40 \mu \mathrm{L}$ of pyridine or sym.-collidine were added while stirring and the reaction mixture was heated to reflux for $24 \mathrm{~h}$. The solvents were removed under reduced pressure and the resulting off-white residue was re-dissolved in a minimal amount of $\mathrm{MeOH}$. The product was precipitated out of solution with $\mathrm{Et}_{2} \mathrm{O}$ and the precipitate was filtered and dried. 


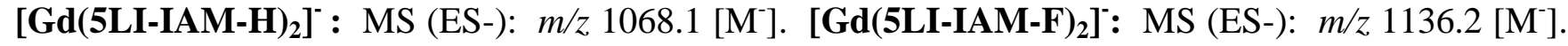
Anal. Calcd. (Found) for $\mathrm{C}_{46} \mathrm{H}_{40} \mathrm{~F}_{4} \mathrm{GdN}_{8} \mathrm{O}_{12} \cdot \mathrm{Na}^{+} \cdot \mathrm{NaCl} \cdot 9 \mathrm{H}_{2} \mathrm{O}$ : C, 39.98 (39.80); H, 4.81 (4.52); N,

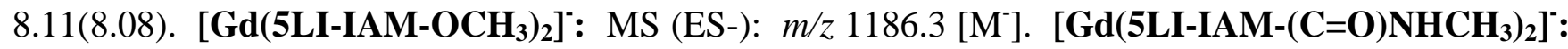

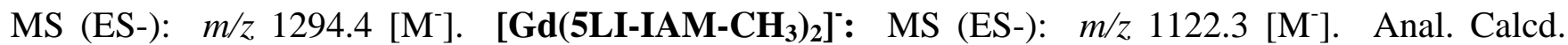
(Found) for $\mathrm{C}_{50} \mathrm{H}_{60} \mathrm{GdN}_{8} \mathrm{O}_{12} \cdot \mathrm{Na}^{+} \cdot 2 \mathrm{NaCl} \cdot 6 \mathrm{H}_{2} \mathrm{O} \cdot \mathrm{CH}_{3} \mathrm{OH}$ : C, 43.80 (43.40); H, 5.19 (4.89); N, 8.01 (7.99).

[Gd(5LI-IAM-Cl) $\left.]_{2}\right]^{-}: \quad$ MS $\quad$ (ES-): $\quad \mathrm{m} / \mathrm{z} \quad 1204.1 \quad\left[\mathrm{M}^{-}\right] . \quad$ Anal. Calcd. (Found) for $\mathrm{C}_{46} \mathrm{H}_{48} \mathrm{Cl}_{4} \mathrm{GdN}_{8} \mathrm{O}_{12} \cdot \mathrm{Na}^{+} \cdot \mathrm{NaCl} \bullet 8 \mathrm{H}_{2} \mathrm{O} \cdot \mathrm{CH}_{3} \mathrm{OH}: \quad \mathrm{C}, 38.65$ (38.90); H, 4.51 (4.29); N, 7.84 (7.56). $\left[\mathbf{G d}\left(5 \mathrm{LI}-\mathrm{IAM}-\mathrm{NO}_{2}\right)_{2}\right]^{*}: \quad$ MS $\quad$ (ES-): $\quad \mathrm{m} / \mathrm{z} \quad 1248.2 \quad\left[\mathrm{M}^{-}\right] . \quad$ Anal. Calcd. (Found) for $\mathrm{C}_{46} \mathrm{H}_{48} \mathrm{GdN}_{12} \mathrm{O}_{20} \cdot \mathrm{Na}^{+} \cdot \mathrm{NaCl} \bullet 6 \mathrm{H}_{2} \mathrm{O}: \mathrm{C}, 38.47$ (38.35); H, 4.21 (4.30); N, 11.71 (11.24). [Gd(5LI-IAM$\left.\left.\mathbf{S O}_{3}\right)_{2}\right]^{5-}$ : Anal. Calcd. (Found) for $\mathrm{C}_{46} \mathrm{H}_{48} \mathrm{GdN}_{8} \mathrm{O}_{24} \mathrm{~S}_{4} \cdot 3 \mathrm{C}_{5} \mathrm{H}_{7} \mathrm{~N}^{+} \cdot \mathrm{Na}^{+} \cdot 9 \mathrm{H}_{2} \mathrm{O}$ : C, 40.52 (40.49); H, 4.68 (4.54); N, 8.52 (8.46). [Gd(5LI-IAM-Br) $]^{-}$: $\quad$ MS (ES-): m/z 1381.9 [M-1. Calcd. (Found) for $\mathrm{C}_{46} \mathrm{H}_{48} \mathrm{Br}_{4} \mathrm{GdN}_{8} \mathrm{O}_{12} \cdot \mathrm{Na}^{+} \cdot \mathrm{NaCl} \cdot 7 \mathrm{H}_{2} \mathrm{O}: \mathrm{C}, 34.76$ (34.82); H, 3.93 (3.76); N, 7.05 (6.82).

Photophysical Measurements. Absorption spectra were recorded on a Cary 300 UV-Visible spectrophotometer using a $1 \mathrm{~cm}$ quartz cell. Emission spectra were recorded on a FluoroLog - 3 (JobinYvon) fluorimeter using a $1 \mathrm{~cm}$ Supracil quartz luminescence cell (room-temperature measurements). The $\mathrm{Tb}(\mathrm{III})$ complexes $(10 \mu \mathrm{M})$ were prepared in situ in $0.1 \mathrm{M}$ Tris buffered $\mathrm{H}_{2} \mathrm{O}(\mathrm{pH}$ 7.4) with $0.2 \%$ DMSO. Quantum yields were determined by the optically dilute method ${ }^{49}$ using the following equation:

$$
Q_{x} / Q_{r}=\left[A_{r}\left(\lambda_{r}\right) / A_{x}\left(\lambda_{x}\right)\right]\left[I\left(\lambda_{r}\right) / I\left(\lambda_{x}\right)\right]\left[n_{x}^{2} / n_{r}^{2}\right]\left[D_{x} / D_{r}\right]
$$

where $A$ is the absorbance at the excitation wavelength $(\lambda), I$ is the intensity of the excitation light at the same wavelength, $n$ is the refractive index and $D$ is the integrated intensity. Quinine sulfate in $1.0 \mathrm{~N}$ sulfuric acid was used as the reference $\left(Q_{r}=0.546\right){ }^{41}$ Low temperature $(77 \mathrm{~K})$ emission 
(phosphorescence) spectra of Gd(III) complexes were recorded on a Cary Eclipse fluorimeter. The $\mathrm{Gd}(\mathrm{III})$ complex solutions were prepared from the isolated complexes (in 1: $4 \mathrm{MeOH}: \mathrm{EtOH}){ }^{50}$

DFT Calculations. Computational studies were conducted at the Molecular Graphics and Computation Facility, College of Chemistry, University of California, Berkeley. Density functional theory and time-dependent density functional theory calculations were performed using a B3LYP/6$311++\mathrm{G}(\mathrm{d}, \mathrm{p})$ basis set in Gaussian 03. The input structure was derived from the crystal structure of a previously reported IAM-Eu(III) complex (CSD reference code: EMEVUN). ${ }^{22}$ Geometry optimizations were performed on the input structures without symmetry constraints.

\section{Acknowledgements}

This research is supported by the Director, Office of Science, Office of Basic Energy Sciences, and the Division of Chemical Sciences, Geosciences, and Biosciences of the U.S. Department of Energy at LBNL under Contract No. DE-AC02-05CH11231. We acknowledge the help of Drs. Nail Chavaleev and Modi Wetzler and Prof. Gilles Muller for use of his fluorimeter.

\section{Supporting Information}

Full citation for reference 47 . Room temperature absorption and emission spectra of the $\mathrm{Tb}(\mathrm{III})$ complexes as well as low temperature $(77 \mathrm{~K})$ emission spectra of the Gd(III) complexes. Also, the lowtemperature emission spectra of $\mathbf{T b}-\mathbf{N O}_{2}$ and $\mathbf{T b}-\mathbf{O C H} \mathbf{C H}_{3}$ This material is available free of charge via the Internet at http://pubs.acs.org.

\section{References}

(1) Lavis, L. D.; Raines, R. T. ACS Chem. Biol. 2008, 3, 142-155. 
(2) Ulrich, G.; Ziessel, R.; Harriman, A. Angew. Chem. Int. Ed. 2008, 47, 1184-1201.

(3) Zimmer, M. Chem. Rev. 2001, 102, 759-781.

(4) Giepmans, B. N. G.; Adams, S. R.; Ellisman, M. H.; Tsien, R. Y. Science 2006, 312, 217-224.

(5) Lo, K. K.-W. In Photofunctional Transition Metal Complexes; Springer Berlin/Heidelberg: 2007; Vol. 123, p 205-245.

(6) Bunzli, J.-C.; Piguet, C. Chem. Soc. Rev. 2005, 34, 1048-1077.

(7) Medintz, I. L.; Uyeda, H. T.; Goldman, E. R.; Mattoussi, H. Nat. Mater. 2005, 4, 435-446.

(8) Fu, A.; Gu, W.; Larabell, C.; Alivisatos, A. P. Curr. Opin. Neurobiol. 2005, 15, 568-575.

(9) Michalet, X.; Pinaud, F. F.; Bentolila, L. A.; Tsay, J. M.; Doose, S.; Li, J. J.; Sundaresan, G.;

Wu, A. M.; Gambhir, S. S.; Weiss, S. Science 2005, 307, 538-544.

(10) Hemmila, I.; Laitala, V. J. Fluor. 2005, 15, 529-542.

(11) Sabbatini, N.; Guardigli, M.; Lehn, J.-M. Coord. Chem. Rev. 1993, 123, 201-228.

(12) Mukkala, V.-M.; Kankare, J. J. Helv. Chim. Acta 1992, 75, 1578-1592.

(13) Alpha, B.; Lehn, J.-M.; Mathis, G. Angew. Chem. Int. Ed. 1987, 26, 266-167.

(14) Alpha, B.; Balzani, V.; Lehn, J.-M.; Perathoner, S.; Sabbatini, N. Angew. Chem. Int. Ed. 1987, 26, $1266-1267$.

(15) Charbonniere, L. J.; Balsiger, C.; Schenk, K. J.; Bunzli, J.-C. G. J. Chem. Soc., Dalton Trans. 1998, 505-510.

(16) Bunzli, J.-C. G.; Ihringer, F. Inorg. Chim. Acta 1996, 246, 195-205.

(17) Bunzli, J.-C. G.; Froidevaux, P.; Harrowfield, J. M. Inorg. Chem. 1993, 32, 3306-3311.

(18) George, M. R.; Golden, C. A.; Grossel, M. C.; Curry, R. J. Inorg. Chem. 2006, 45, 1739-1744.

(19) Lamture, J. B.; Zhou, Z. H.; Kumar, A. S.; Wensel, T. G. Inorg. Chem. 1995, 34, 864-869.

(20) de Sa, G. F.; Malta, O. M.; Donega, C. D.; Simas, A. M.; Longo, R. L.; Santa-Cruz, P. A.; de Silva, E. F. Coord. Chem. Rev. 2000, 196, 165-195.

(21) Deandrade, A. V. M.; Dacosta, N. B.; Simas, A. M.; Desa, G. F. Chem. Phys. Lett. 1994, 227, 349-353.

(22) Petoud, S.; Cohen, S. M.; Bunzli, J.-C.; Raymond, K. J. Am. Chem. Soc. 2003, 125, 1332413325.

(23) Petoud, S.; Muller, G.; Moore, E. G.; Xu, J.; Sokolnicki, J.; Riehl, J. P.; Le, U. N.; Cohen, S. M.; Raymond, K. N. J. Am. Chem. Soc. 2007, 129, 77-83.

(24) Seitz, M.; Moore, E. G.; Ingram, A. J.; Muller, G.; Raymond, K. N. J. Am. Chem. Soc. 2007, 129, 15468-15470.

(25) http://www.lumiphore.com. 
(26) Chen, J.; Selvin, P. R. J. Photochem. Photobiol. 2000, 135, 27-32.

(27) Deum, R. V.; Fias, P.; Driesen, K.; Binnemans, K.; Gorller-Walrand, C. Phys. Chem. Chem. Phys 2003, 5, 2754-2757.

(28) de Bettencourt-Dias, A. Inorg. Chem. 2005, 44, 2734-2741.

(29) de Bettencourt-Dias, A.; Viswanathan, S. Dalton Trans. 2006, 34, 4093-4103.

(30) Guillaumont, D.; Bazin, H.; Benech, J.-M.; Boyer, M.; Mathis, G. Chem. Phys. Chem. 2007, 8, 480-488.

(31) Latva, M.; Takalo, H.; Mukkala, V.-M.; Matachescu, C.; Rodriguez-Ubis, J. C.; Kankare, J. J. Lumin. 1997, 75, 149-169.

(32) Sato, N.; Shinkai, S. J. Chem. Soc. Perkin Trans. 2 1993, 4, 621-624.

(33) Shi, M.; Li, F.; Yi, T.; Zhang, D.; Hu, H.; Huang, C. Inorg. Chem. 2005, 44, 8929-8936.

(34) Beeby, A.; Bushby, L. M.; Maffeo, D.; Williams, J. A. G. J. Chem. Soc., Dalton Trans. 2002, 1, 48-54.

(35) Slama, J.; Rando, R. R. Carbohydr. Res. 1981, 88, 213-221.

(36) Raymond, K. N.; Petoud, S.; Cohen, S. M.; Xu, J. USA, 2003; Vol. 6515113 B2.

(37) Ross, D. L.; Reissner, E. J. Org. Chem 1966, 31, 2571-2580.

(38) Alpha, B.; Ballardini, R.; Balzani, V.; Lehn, J.-M.; Perathoner, S.; Sabbatini, N. Photochem. Photobiol. 1990, 52, 299-309.

(39) Hansch, C.; Leo, A.; Taft, R. W. Chem. Rev. 1991, 91, 165-195.

(40) Liddle, B. J.; Silva, R. M.; Morin, T. J.; Macedo, F. P.; Shukla, R.; Lindeman, S. V.; Gardinier, J. R. J. Org. Chem 2007, 72, 5637-5646.

(41) Meech, S. R.; Philips, D. J. Photochem. 1983, 23, 193-217.

(42) Sato, S.; Wada, M. Bull. Chem. Soc. Japan 1970, 43, 1955-1962.

(43) Leonard, J. P.; Nolan, C. B.; Stomeo, F.; Gunnlaugsson, T. In Topics in Current Chemistry; Springer-Verlag Berlin: Berlin, 2007; Vol. 281, p 1-43.

(44) Beeby, A.; Clarkson, I. M.; Dickins, R. S.; Faulkner, S.; Parker, D.; Royle, L.; Sousa, A. S. d.; Williams, J. A. G.; Woods, M. J. Chem. Soc. Perkin Trans. 2 1999, 493-503.

(45) Bunzli, J.-C. G. In Lanthanide Probes in Life, Chemical and Earth Sciences: Theory and Practice; Bunzli, J.-C. G., Choppin, G. R., Eds.; Elsevier: Amsterdam, 1989.

(46) Frisch, M. J. et al. Gaussian 03; revision C.01 ed.; Gaussian, Inc: Wallingford, CT, 2004.

(47) Gutierrez, F.; Tedeschi, C.; Maron, L.; Daudey, J. P.; Azema, J.; Tisnes, P.; Picard, C.; Poteau, R. THEOCHEM 2005, 756, 151-162. 
(48) Lackowicz, J. R. Principles of Fluorescence Spectroscopy; 2nd ed.; Kluwer Academic/Plenum Publishers: New York, 1999.

(49) Crosby, G. A.; Demas, J. N. J. Phys. Chem. 1971, 75, 991-1024.

(50) Scott, D. R.; Allison, J. B. J. Phys. Chem. 1962, 66, 561-562. 
<smiles>[X]c1cc(C(=O)NC)c(O)c(C(=O)NCCCCCNC(=O)c2cc([X])cc(C(=O)NC)c2O)c1</smiles>

Figure 1. Structure of 5LI-IAM-X ligands $\left(\mathrm{X}=\mathrm{H}, \mathrm{CH}_{3},(\mathrm{C}=\mathrm{O}) \mathrm{NHCH}_{3}, \mathrm{SO}_{3}{ }^{-}, \mathrm{NO}_{2}, \mathrm{OCH}_{3}, \mathrm{~F}, \mathrm{Cl}, \mathrm{Br}\right)$

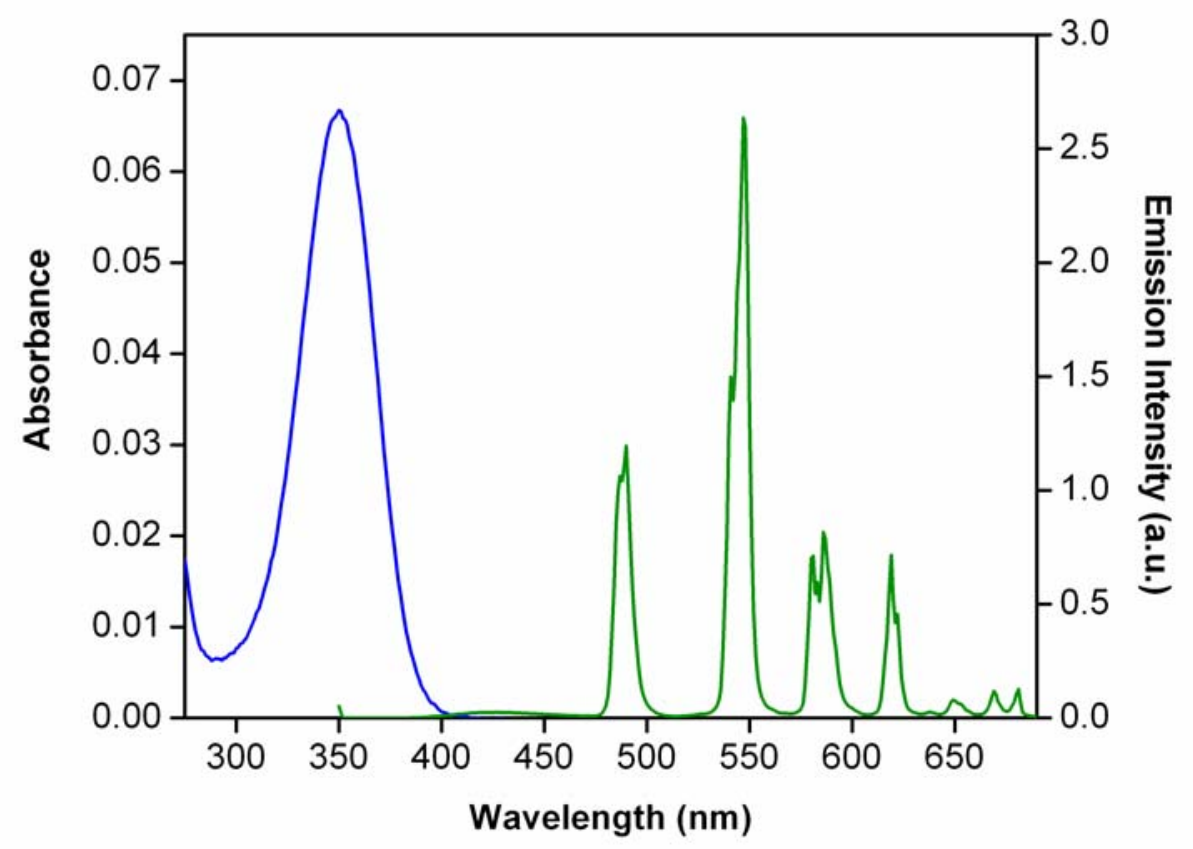

Figure 2. Absorption (blue) and emission (green) spectra of Tb-Cl $\left(\lambda_{\mathrm{ex}}=350 \mathrm{~nm}\right)$. Absorption and emission spectra for the entire IAM-X series can be found in the Supporting Information (Figures S1S8). 


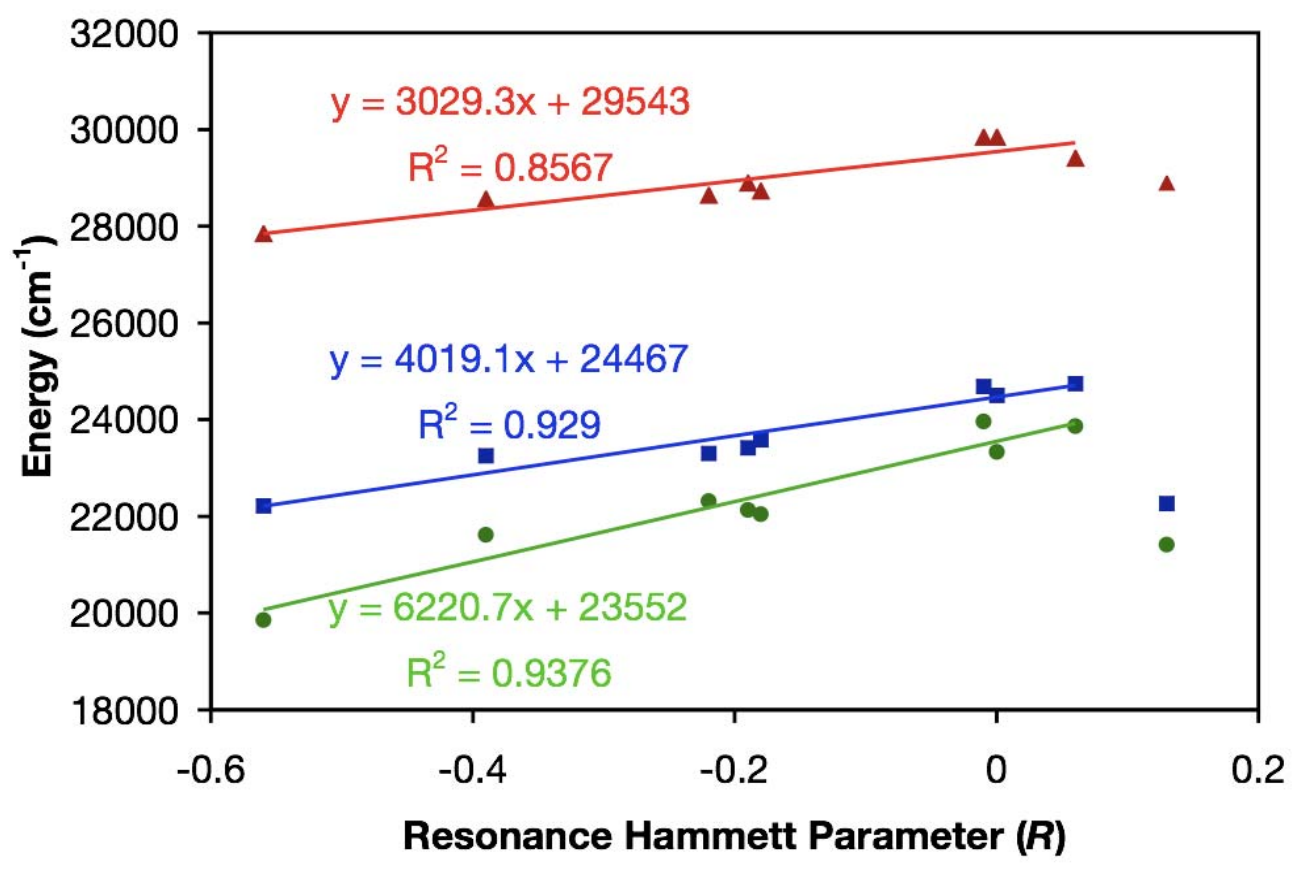

Figure 3. Linear relationships between ligand absorption maxima ( ), fluorescence maxima (1/4), and triplet energies $(\mu)$ and the resonance component of the Hammett parameter of the substituents $(\boldsymbol{R})$ 


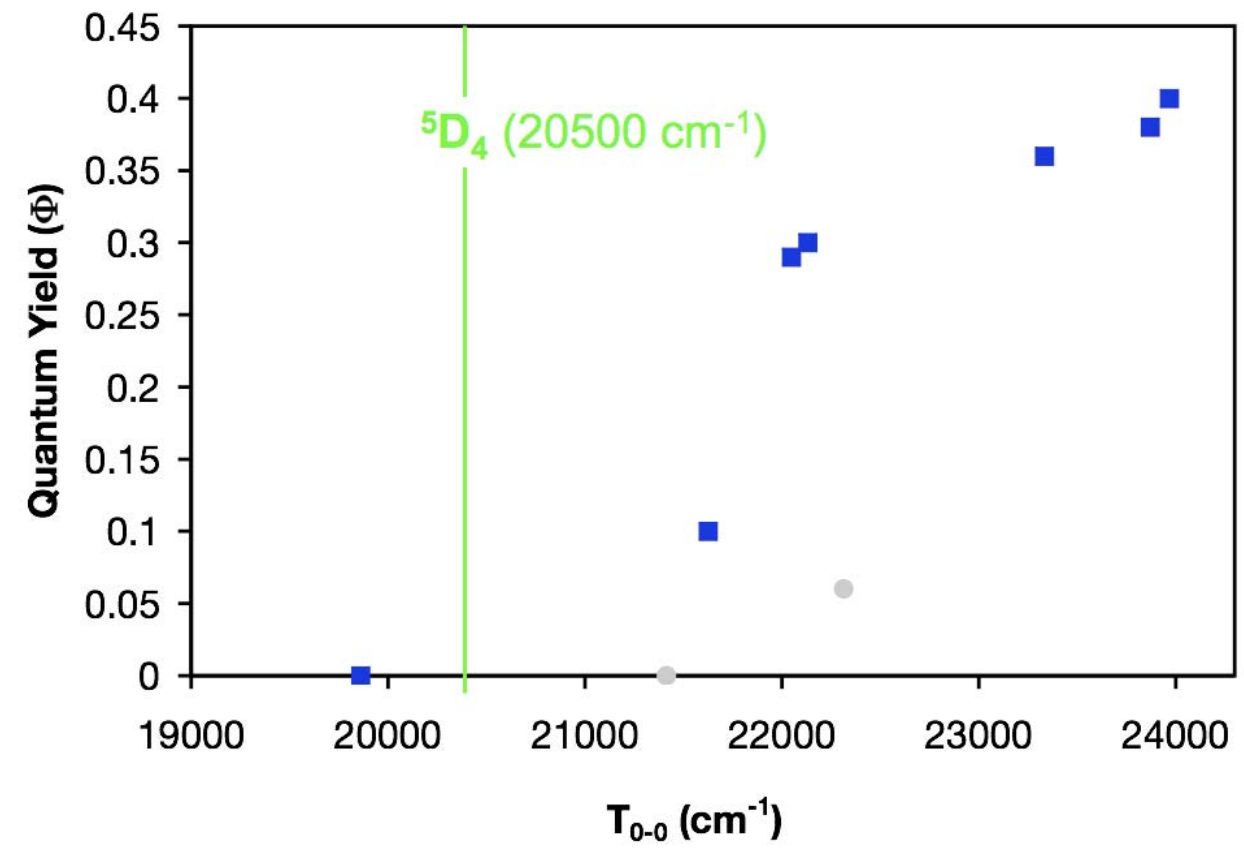

Figure 4. Relationship between the ligand triplet energies $\left(\mathrm{T}_{0-0}\right)$ and the quantum yields $(\Phi)$ of the corresponding $\mathrm{Tb}(\mathrm{III})$ complexes. $\mathbf{T b}-\mathbf{N O}_{2}$ and $\mathbf{T b}-\mathbf{B r}$, which experience quenching due to an ILCT state and possible heavy-atom effects, respectively, are shown as $\mu$. 


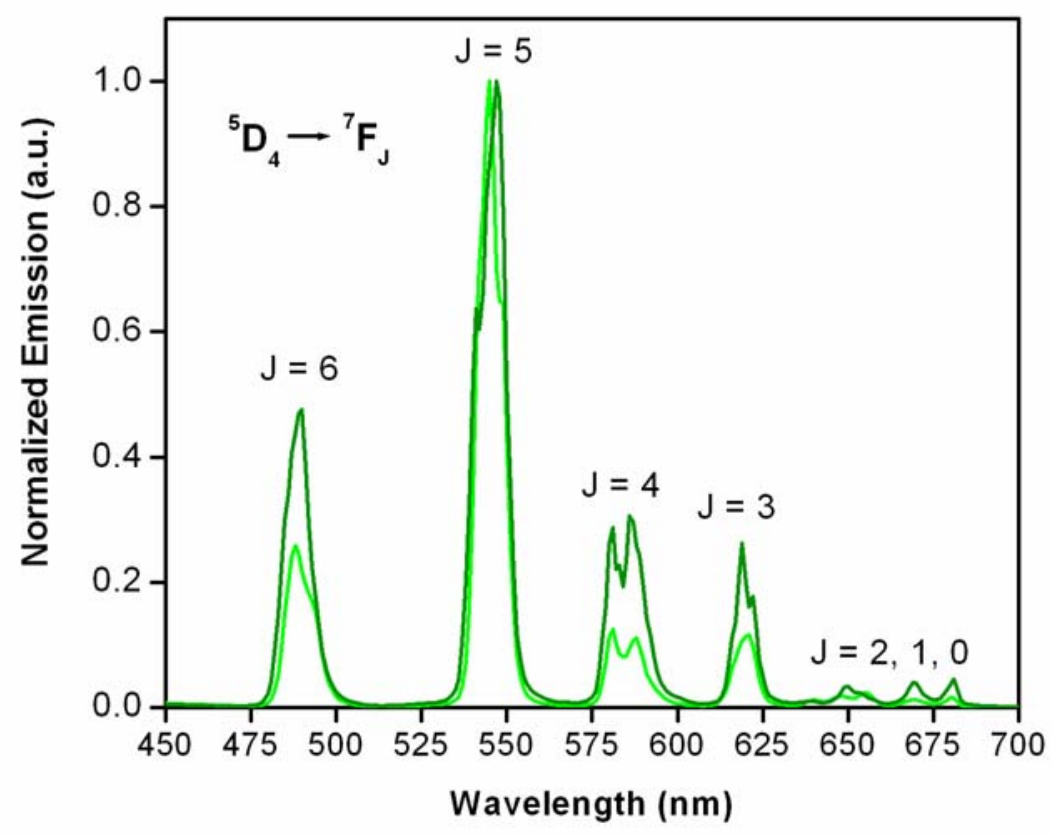

Figure 5. Emission spectra of $\mathbf{T b}-\mathbf{H}(\mathbf{1 0 f})$ (dark green, $\lambda_{\mathrm{ex}}=335 \mathrm{~nm}$ ) and $\mathbf{T b}-\mathbf{S O}_{\mathbf{3}}^{-}(\mathbf{1 0 i})$ (light green, $\left.\lambda_{\text {ex }}=340 \mathrm{~nm}\right)$ normalized to the intensity of the ${ }^{5} \mathrm{D}_{4} \rightarrow{ }^{7} \mathrm{~F}_{5}$ transition $\left(C=10^{-5} \mathrm{M}, 0.1 \mathrm{M}\right.$ TRIS, pH 7.4, $0.2 \%$ DMSO).

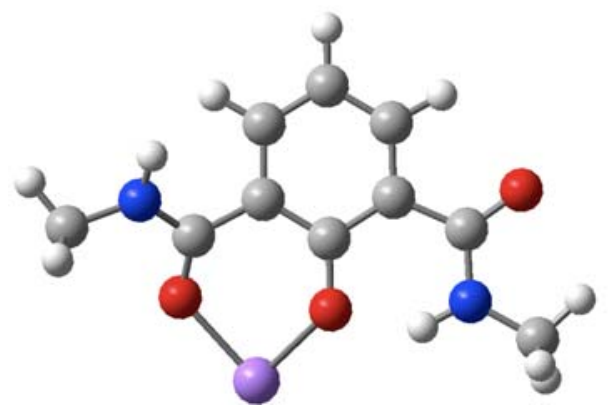

Figure 6. Representative TD-DFT input structure. The ligand is approximated as a single bidentate binding unit and the $\mathrm{Tb}(\mathrm{III})$ is replaced with $\mathrm{Na}^{+}$(purple). 


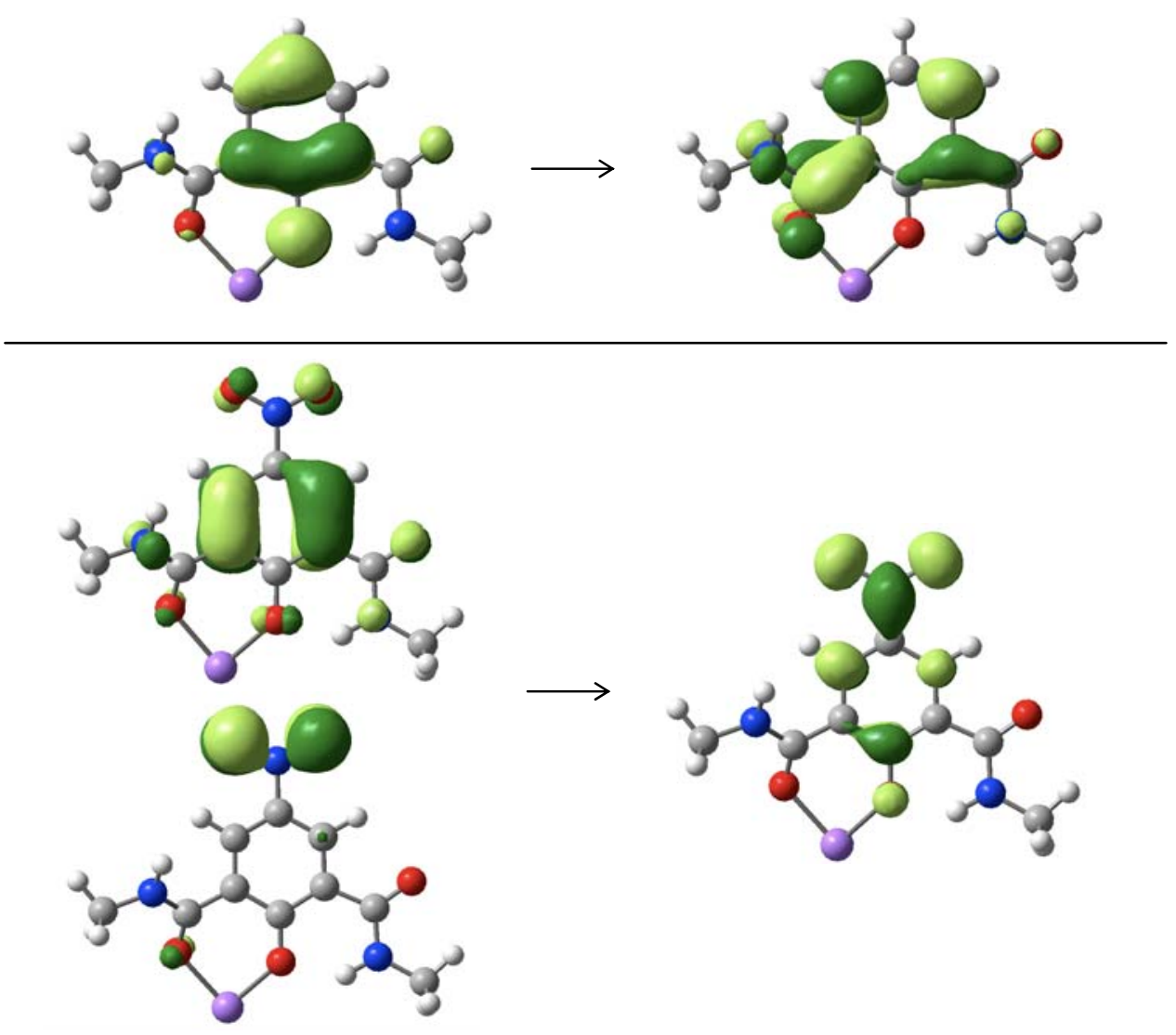

Figure 7. Representative molecular orbitals showing $\pi-\pi^{*} \mathrm{~S}_{0} \rightarrow \mathrm{T}_{1}$ transition for IAM-H (top) and ILCT $\mathrm{S}_{0} \rightarrow \mathrm{T}_{1}$ transition for IAM-NO $\mathrm{N}_{2}$ (bottom). 
Scheme 1. Synthesis of 5LI-IAM-X ligand series
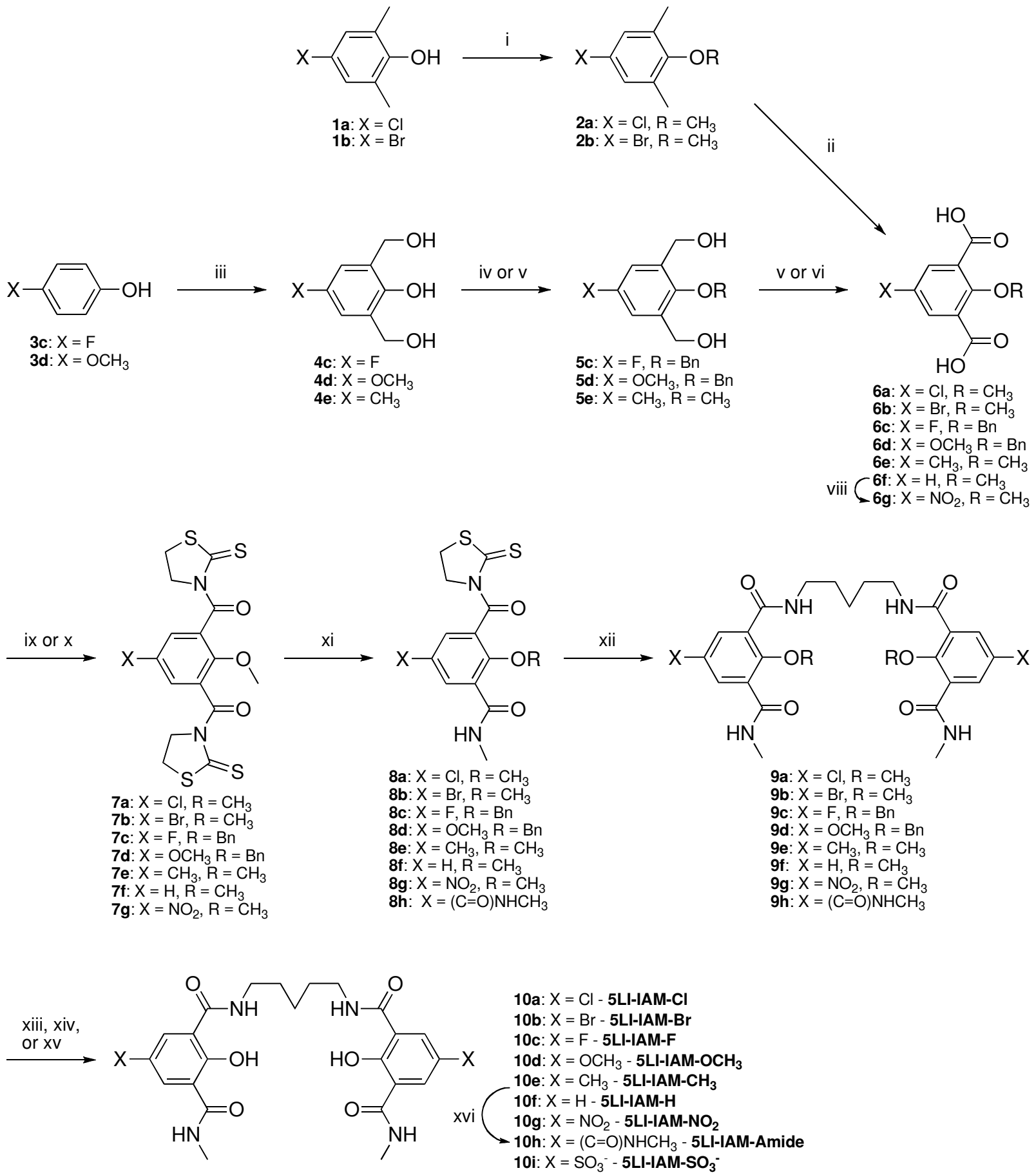

Reagents and conditions: (i) DMS, $\mathrm{K}_{2} \mathrm{CO}_{3}$, acetone, $56{ }^{\circ} \mathrm{C}$; (ii) $\mathrm{KMnO}_{4}, \mathrm{KOH}, \mathrm{H}_{2} \mathrm{O}, 100{ }^{\circ} \mathrm{C}$; (iii) paraformaldehyde, $\mathrm{NaOH}, \mathrm{H}_{2} \mathrm{O}, 30{ }^{\circ} \mathrm{C}$; (iv) benzyl chloride, $\mathrm{K}_{2} \mathrm{CO}_{3}, \mathrm{DMF}, 75{ }^{\circ} \mathrm{C}$; (v) DMS, NaOH, $\mathrm{H}_{2} \mathrm{O}, 25^{\circ} \mathrm{C}$; (vi) $\mathrm{CrO}_{3} / \mathrm{H}_{2} \mathrm{SO}_{4}$, acetone, $25{ }^{\circ} \mathrm{C}$; (vii) $\mathrm{KMnO}_{4}, \mathrm{KOH}, \mathrm{H}_{2} \mathrm{O}, 0{ }^{\circ} \mathrm{C}$; (viii) $1: 2 \mathrm{HNO}_{2}: \mathrm{H}_{2} \mathrm{SO}_{4}, 0$ ${ }^{\circ} \mathrm{C}$; (ix) 1. thionyl chloride, dioxane, $100{ }^{\circ} \mathrm{C} 2$. 2-mercaptothiazoline, $\mathrm{NEt}_{3}, \mathrm{CH}_{2} \mathrm{Cl}_{2},-78-25{ }^{\circ} \mathrm{C}$; (x) 1. oxalyl chloride, benzene, $50{ }^{\circ} \mathrm{C}$ 2. 2-mercaptothiazoline, $\mathrm{NEt}_{3}, \mathrm{CH}_{2} \mathrm{Cl}_{2}, 0-25{ }^{\circ} \mathrm{C}$; (xi) $\mathrm{CH}_{3} \mathrm{NH}_{2}, \mathrm{MeOH}$, $\mathrm{CH}_{2} \mathrm{Cl}_{2}$; (xii) 1,5-diaminopentane, $\mathrm{CH}_{2} \mathrm{Cl}_{2}$; (xiii) $\mathrm{BBr}_{3}, \mathrm{CH}_{2} \mathrm{Cl}_{2},-78-25{ }^{\circ} \mathrm{C}$; (xiv) 1:1 $\mathrm{HOAc}$ : $\mathrm{HCl}$; (xv) $\mathrm{Pd} / \mathrm{C}, \mathrm{HOAc}, \mathrm{MeOH}, \mathrm{H}_{2}$; (xvi) $\mathrm{H}_{2} \mathrm{SO}_{4}$. 
Table 1. Summary of photophysical data for Tb(III)-5LI-IAM-X complexes $\left(C=10^{-5} \mathrm{M}, 0.1 \mathrm{M}\right.$ TRIS buffer $\mathrm{pH}=7.4\left(0.2 \%\right.$ DMSO, $\left.\lambda_{\mathrm{exc}}=\lambda_{\max }{ }^{\mathrm{ab}}\right)$.

\begin{tabular}{|c|c|c|c|c|c|c|c|c|c|c|c|}
\hline \multirow[b]{2}{*}{ Ligand } & \multirow[b]{2}{*}{$X$} & \multirow{2}{*}{$\begin{array}{c}\lambda_{\max }^{a b} \\
(\mathrm{~nm})\end{array}$} & \multirow{2}{*}{$\begin{array}{c}\varepsilon \\
\left(\mathrm{M}^{-1} \mathrm{~cm}^{-1}\right)\end{array}$} & \multirow{2}{*}{$\begin{array}{l}\lambda_{\max }^{\mathrm{fl}} \\
(\mathrm{nm})\end{array}$} & \multirow{2}{*}{$\begin{array}{c}\mathrm{T}_{0-0}^{a} \\
\left(\mathrm{~cm}^{-1}\right)\end{array}$} & \multicolumn{2}{|c|}{$\tau(\mathrm{ms}) @ \mathrm{RT}$} & \multirow[b]{2}{*}{$q^{b}$} & \multicolumn{2}{|c|}{$\tau(\mathrm{ms}) @ 77 \mathrm{~K}^{c}$} & \multirow[b]{2}{*}{$\Phi^{d}$} \\
\hline & & & & & & $\mathrm{H}_{2} \mathrm{O}$ & $\mathrm{D}_{2} \mathrm{O}$ & & $\mathrm{H}_{2} \mathrm{O}$ & $\mathrm{D}_{2} \mathrm{O}$ & \\
\hline 10h & Amide & 335 & 19100 & 405 & 23970 & 2.22 & 2.49 & -0.1 & 2.17 & 2.57 & 0.40 \\
\hline $10 i$ & $\mathrm{SO}_{3}^{-}$ & 340 & 24700 & 404 & 23870 & 1.23 & 1.42 & 0.2 & 1.12 & 1.22 & 0.38 \\
\hline $10 f$ & $\mathrm{H}$ & 335 & 25100 & 408 & 23330 & 2.52 & 2.81 & -0.1 & 2.46 & 3.11 & 0.36 \\
\hline $10 b$ & $\mathrm{Br}$ & 349 & 20100 & 429 & 22310 & 0.943 & 1.18 & $\mathrm{n} / \mathrm{a}$ & 2.28 & 2.87 & 0.06 \\
\hline $10 a$ & $\mathrm{Cl}$ & 346 & 22100 & 427 & 22130 & 1.98 & 2.15 & -0.1 & 2.39 & 2.89 & 0.30 \\
\hline $10 \mathrm{e}$ & $\mathrm{CH}_{3}$ & 348 & 22200 & 424 & 22050 & 2.04 & 2.31 & 0 & 2.57 & 3.15 & 0.29 \\
\hline 10c & F & 350 & 26200 & 430 & 21630 & 0.651 & 0.847 & $\mathrm{n} / \mathrm{a}$ & 2.58 & 3.17 & 0.10 \\
\hline $10 \mathrm{~g}$ & $\mathrm{NO}_{2}$ & 346 & 54400 & 449 & 21410 & - & - & - & 1.56 & 1.62 & 0 \\
\hline 10d & $\mathrm{OCH}_{3}$ & 359 & 22500 & 450 & 19860 & - & - & - & 2.67 & 3.22 & 0 \\
\hline
\end{tabular}

${ }^{a} \mathrm{~T}_{0-0}$ values obtained by deconvolution of emission spectra of Gd(III) complexes (77K, 1:4 $\mathrm{MeOH}: \mathrm{EtOH})$ to determine 0-0 vibrational transition energy. ${ }^{b}$ Calculated from room-temperature lifetime values using $q=5 \times\left(1 / \tau_{\mathrm{H} 2 \mathrm{O}}-1 / \tau_{\mathrm{D} 2 \mathrm{O}}-0.06\right) .{ }^{44}{ }^{c}$ Samples contained $10 \%(\mathrm{v} / \mathrm{v})$ glycerol. ${ }^{d}$ Error $\sim 10 \%$ based on duplicate measurements.

Table 2. Summary of calculated singlet $\left(\mathrm{S}_{1}{ }^{\text {calc }}\right)$ and triplet $\left(\mathrm{T}_{1}{ }^{\text {calc }}\right)$ energies compared to experimental absorption maxima $\left(\lambda_{\max }{ }^{a b}\right)$ and $T_{0-0}$ energies.

\begin{tabular}{ccccc}
\hline $\mathrm{X}$ & $\begin{array}{c}\lambda_{\max }{ }^{\mathrm{ab}} \\
(\mathrm{nm})\end{array}$ & $\begin{array}{c}\mathrm{S}_{1}{ }^{\text {calc }} \\
(\mathrm{nm})\end{array}$ & $\begin{array}{c}\mathrm{T}_{0-0} \\
(\mathrm{~nm})\end{array}$ & $\begin{array}{c}\mathrm{T}_{1}{ }^{\text {calc }} \\
(\mathrm{nm})\end{array}$ \\
\hline Amide & 335 & 339 & 417 & 421 \\
$\mathrm{SO}_{3}{ }^{-a}$ & 340 & 339 & 419 & 421 \\
$\mathrm{H}$ & 335 & 342 & 429 & 430 \\
$\mathrm{Br}$ & 349 & 355 & 448 & 454 \\
$\mathrm{CH}_{3}$ & 346 & 353 & 454 & 452 \\
$\mathrm{Cl}$ & 348 & 351 & 452 & 451 \\
$\mathrm{~F}$ & 350 & 354 & 462 & 466 \\
$\mathrm{NO}_{2}$ & 346 & 354 & 467 & 498 \\
$\mathrm{OCH}_{3}$ & 359 & 383 & 504 & 514
\end{tabular}

\footnotetext{
${ }^{a}$ Input structure contained an additional $\mathrm{Na}^{+}$counter-ion to balance the charge.
} 
SYNOPSIS TOC: A series of nine para-substituted antenna ligands have been prepared to study the effects of ligand substitution on $\mathrm{Tb}(\mathrm{III})$ emission in an effort to develop a predictive model of the photophysical behavior of antenna chromophores and their resulting $\mathrm{Tb}(\mathrm{III})$ complexes. Emission spectra show that the ligand singlet and triplet energies increase linearly with the resonance Hammett parameter $(\boldsymbol{R})$ of the substituent and that the quantum yields of the $\mathrm{Tb}(\mathrm{III})$ complexes increase with the ligand triplet energies; TD-DFT calculations performed on simplified $\mathrm{Na}^{+}$analogs of the $\mathrm{Tb}(\mathrm{III})$ reproduce experimental ligand triplet energies within $\sim 5 \%$. Together, the experimental and computational results serve as a predictive tool that can be used to guide antenna ligand design.
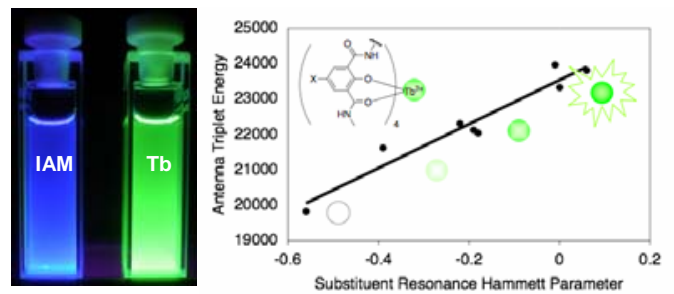